\title{
Review of Small-Scale Tubular Anaerobic Digesters Treating Livestock Waste in the Developing World
}

1. Maureen N. Kinyua

Department of Civil and Environmental Engineering, University of South Florida, 4202 E Fowler Ave ENB 118 Tampa, FL 33620

mkinyua@mail.usf.edu

2. Laurel E. Rowse

Affiliation address: Department of Civil and Environmental Engineering, University of South Florida, 4202 E Fowler Ave ENB 118 Tampa, FL 33620

Current address: URS Corporation, 7650 W Courtney Campbell Causeway Ste 700, Tampa, FL 33607

laurel.rowse@gmail.com

3. Sarina J. Ergas*

Department of Civil and Environmental Engineering, University of South Florida, 4202 E Fowler Ave ENB 118 Tampa, FL 33620

sergas@usf.edu

813-974-1119

* Corresponding author 


\begin{abstract}
Small-scale tubular anaerobic digesters are an attractive technology for treatment of livestock waste in the developing world. These systems produce biogas (a mixture of $\mathrm{CH}_{4}$ and $\mathrm{CO}_{2}$ ) that is mainly used for cooking. Digester effluent is rich in nutrients (nitrogen and phosphorus) and can be used as a soil amendment. These systems also assist in mitigating deforestation by providing an alternative fuel source, reducing water pollution due to runoff of untreated livestock waste, decreasing air pollution from biomass combustion and promoting gender equality. However, for these benefits to be significant, the effects of design, substrate characteristics and operating parameters on system performance must be understood. This review provides a detailed summary of the research that has been conducted on tubular anaerobic digesters treating livestock waste in developing countries. Links between successful digester performance and energy, environmental, public health and social benefits are also provided. In addition, this review discusses governmental policies that have successfully increased adoption of livestock waste anaerobic digestion systems in Africa, Asia and Latin America.
\end{abstract}

\title{
Keywords
}

Benefits; Biogas; Energy; International Development; Livestock Waste; Tubular digester 


\section{List of Acronyms}

\begin{tabular}{|c|c|}
\hline $\mathrm{ADB}$ & Asian Development Bank \\
\hline ALRI & Acute Lower Respiratory Infections \\
\hline BOD & Biochemical Oxygen Demand \\
\hline $\mathrm{C} / \mathrm{N}$ & Carbon Nitrogen ratio \\
\hline COD & Chemical Oxygen Demand \\
\hline COPD & Chronic Obstructive Pulmonary Disease \\
\hline FOG & Fats, Oils and Grease \\
\hline GHG & Greenhouse Gases \\
\hline HRT & Hydraulic Retention Time \\
\hline LCFA & Long Chain Fatty Acids \\
\hline LPG & Liquefied Petroleum Gas \\
\hline $\mathrm{N} / \mathrm{P}$ & Nitrogen Phosphorus ratio \\
\hline NBP & National Biogas Programme \\
\hline NGO & Non-Governmental Organization \\
\hline NREL & National Renewable Energy Laboratory \\
\hline OLR & Organic Loading Rate \\
\hline PRC & People's Republic of China \\
\hline SRT & Solids Retention Time \\
\hline TAN & Total Ammonia Nitrogen \\
\hline VFA & Volatile Fatty Acids \\
\hline VOC & Volatile Organic Compounds \\
\hline VS & Volatile Solids \\
\hline
\end{tabular}


WTE Waste to Energy

11

12

13

14

15

16

17

18

19

20

21

22

23

24

25

26

27

28

29

30

31

32

33

34

35

36

37

38

39

40

41

42

43

44

45

46

47

48

49

50

51

52

53

54

55

56

57

58

59

60

61

62

63

64

65 


\section{$1 \quad$ Introduction}

Anaerobic digestion of livestock waste is a waste management method that can improve the quality of life of those in the developing world. Biogas produced from small-scale anaerobic digesters is most often used as a cooking fuel, but can also be used to heat water or buildings or generate electricity for on-site use [1-4]. Anaerobic digesters can also be a useful tool to mitigate deforestation by using biogas as opposed to firewood. This also results in decreased public health concerns, especially for women and children who are disproportionally affected by indoor air pollution due to cultural and social roles. In addition, effluent from anaerobic digestion contains primary nutrients (nitrogen, phosphorus, potassium), that have agronomic benefits if used as a soil amendment to improve plant growth. Interrelationships between substrate characteristics, operating parameters and biochemical conditions within the digesters and how these condition translate to energy, environmental, agricultural, social and public health benefits as well as policies promoting anaerobic digestion of livestock waste are shown in Figure 1.

There are three types of small-scale anaerobic digestion systems commonly used in the developing world, fixed dome, floating drum and tubular. Fixed dome digesters are constructed underground, which reduces the cost of constructing load bearing tank walls. They have no metal parts that can rust and have been reported to last as long as 20 years. The main disadvantage of fixed dome digesters is that skilled laborers are required for their construction. In addition, variations in liquid volume, methane production and use and temperature affect gas pressure in the fixed dome, which can lead to burner malfunction [3-6]. Floating drum digesters are widely used in Asia. They are similar to fixed dome digesters but incorporate a floating gas holder that is supported by a guide frame. Gas pressure is constant and biogas volume can be monitored by observing the position of the drum. They are simple to construct but require regular 
maintenance to prevent corrosion, especially in tropical climates [3-6]. Tubular digesters are similar to fixed dome digesters in that they are constructed in ground; however, they are normally constructed from low cost polyethylene tubing, with a separate storage bag for the biogas. Tubular digesters do not require a high level of skilled labor to install, they are the easiest to operate, cost the least and can operate at a variety of temperatures [3-6]. Due to their advantages and popularity, this review provides a detailed summary of the current and ongoing research on tubular digesters treating livestock waste in the developing world. In addition to information from the literature, the authors' observations of design, operation and maintenance of tubular digesters treating livestock waste as well as discussions with farmers and development workers in Monteverde, Costa Rica are also incorporated into this review.

\section{Small-scale Tubular Anaerobic Digesters}

The first plastic tubular digesters were installed in Colombia and Ethiopia in the 1980s by Botero and Preston [7]. After visiting the installed plastic tubular digesters in Colombia in 1992, a Vietnamese group designed a tubular digester using a polyethylene tube and PVC piping. This new design had a lower capital cost compared with using plastic bags. By 1995, more than 800 polyethylene tubular digesters were installed in Vietnam and 100 in Tanzania [8]. This type of digester is now commonly referred to as the Taiwanese-model, double tubular polyethylene bag digester. In this review, it will be referred to as simply a tubular digester.

A side view of a typical tubular digester is shown in Figure 2. Digester length can vary from $8 \mathrm{~m}$ to as long as $40 \mathrm{~m}$, with a circumference of $3.6-5 \mathrm{~m}$ [9-10]. Generally the total volume ranges from 2.4 to $12 \mathrm{~m}^{3}$, with approximately $75 \%$ of the total being working (liquid) volume [11-12]. The polyethylene tube is placed in a 2.0-5.0\% slope deep trench to provide support for the weight of the slurry. Inlet and outlet pipes are installed at a $45^{\circ}$ angle (Figure 2) to maintain 
equal influent and effluent flows [8]. In Costa Rica, a combined grit and flotation chamber is constructed upstream of the inlet section to remove large solid material, such as uneaten animal feed, sand and gravel, that are not biodegradable and can cause wear and tear on the system.

Roof shelters are often used to protect the polyethylene tube from UV radiation and to regulate the temperature inside the digester, due to ambient temperature fluctuations $[8,13]$. Commonly used roof shapes are gable, shed and dome. Depending on the amount of funds available, a polyethylene biogas storage bag can also be installed above the digester. Figure $3 \mathrm{a}$ is a photograph of a tubular digester with a biogas storage bag and Figure $3 \mathrm{~b}$ is a tubular digester without a biogas storage bag. Both images are from digesters installed in the Monteverde region of Costa Rica that are used to treat swine and cow waste. The biogas pipe (Figure. 2) flows into a safety valve that prevents air from getting into the digester or biogas storage bag, while providing an escape for excess biogas [8]. Methane's $\left(\mathrm{CH}_{4}\right)$ greenhouse gas (GHG) potential is 21-24 times greater than carbon dioxide $\left(\mathrm{CO}_{2}\right)$, it is recommended that users burn off excess biogas to avoid high GHG emissions. Biogas contains $\mathrm{CH}_{4}, \mathrm{CO}_{2}$ and traces of hydrogen sulfide $\left(\mathrm{H}_{2} \mathrm{~S}\right)$. Combustion of $\mathrm{H}_{2} \mathrm{~S}$ forms sulfur dioxide, which can cause respiratory diseases such as emphysema and bronchitis [14]. $\mathrm{H}_{2} \mathrm{~S}$ is also a corrosive gas that can reduce the life-span of metal cook stoves. Its rotten eggs smell is also not aesthetically pleasing to users of the biogas when cooking [3]. It is recommended that iron steel wool be placed inside the biogas pipe to scrub the $\mathrm{H}_{2} \mathrm{~S}$ from the biogas, as shown in Equation 1 [15]:

$\mathrm{Fe}_{2} \mathrm{O}_{3}+3 \mathrm{H}_{2} \mathrm{~S} \rightarrow 2 \mathrm{Fe}_{2} \mathrm{~S}_{3}+6 \mathrm{H}_{2} \mathrm{O}$

The iron sulfide $\left(\mathrm{Fe}_{2} \mathrm{~S}_{3}\right)$ produced is not corrosive or toxic; however, scrubbing of the biogas can be dangerous if a leak in the biogas storage bag or biogas pipe is not easily detected due to lack of odor [16]. 


\section{Operation of Tubular Anaerobic Digesters}

Anaerobic digestion is carried out by different groups of microbes in four main steps:

1. Fermentation - Fermenting bacteria hydrolyze complex insoluble molecules, such as proteins, carbohydrates, and lipids, into simpler soluble organic compounds.

2. Acidogenesis - Acidogens utilize the simple soluble organic compounds such amino acids, sugars, alcohols, and fatty acids to produce volatile fatty acids (VFA).

3. Acetogenesis - Acetogens utilize VFAs to produce acetate, $\mathrm{H}_{2}$, and $\mathrm{CO}_{2}$.

4. Methanogenesis - Methanogens produce $\mathrm{CH}_{4}$ by consuming acetate, $\mathrm{H}_{2}$, and $\mathrm{CO}_{2}$

A syntrophic relationship exists between the different groups of microbes, which is vital for the anaerobic digestion process to be successful. For example, if the growth rate of fermenting bacteria is low, the rates of acidogenesis, acetogenesis and methanogenesis are decreased. In this scenario, hydrolysis is the rate limiting step leading to decreased biogas and $\mathrm{CH}_{4}$ production.

Substrate characteristics (type of manure), operating parameters and chemical conditions in the digester affect the complex anaerobic microbial population dynamics which in turn affect the overall performance of the system. Operating parameters include; temperature, retention time, and organic loading rate (OLR). Retention time includes hydraulic retention time (HRT) and solids retention time (SRT). Chemical conditions include; alkalinity, $\mathrm{pH}$, total ammonia nitrogen (TAN) and VFA concentrations. Chemical conditions are controlled by the substrate characteristics and operating parameters. In industrial-scale anaerobic digestion systems, chemical conditions are often carefully monitored and controlled by addition of acids or bases to control $\mathrm{pH}$ and alkalinity, providing heating and mixing or adjusting the OLR to control TAN or VFA inhibition [17]. It is unlikely that households using small-scale tubular digesters can monitor and control the chemical conditions, therefore, only the substrate characteristics and 
operating parameters will be discussed in this review. A summary of the substrates and operating parameters used in countries in Africa, Asia and South and Central America are provided in Table 1.

\subsection{Substrate Characteristics}

Livestock manures commonly used as substrate for small-scale tubular digesters in the developing world include swine, cow, guinea pig, sheep, llama and buffalo (Table 1). The organic portion of livestock manure contains complex insoluble molecules, such as proteins, carbohydrates, and lipids, which are converted to simpler soluble organic compounds. During hydrolysis, recalcitrant compounds in the substrates, such as cell walls, lignin and cellulose, are also degraded. However, fermenting bacteria degrade these compounds at a much slower rate because the extracellular enzymes that catalyze hydrolysis have a difficult time penetrating the lignocellulosic and hemicellulosic structures of these compounds [18].

The hydrolysis rate is affected by the fraction of recalcitrant compounds in the volatile solids (VS); therefore, it is important to know the concentration of these compounds based on the animal. The percent fraction of lignin, cellulose and hemicelluloses in the VS concentration of poultry, swine and cow manure is illustrated in Table 2 [19]. Cow manure has the highest average concentration of recalcitrant compounds. Cows utilize a large fraction of the carbohydrates available in their food for energy; this leaves mostly recalcitrant compounds in the manure [20]. Therefore; depending on the concentration of recalcitrant compounds in the manure, hydrolysis can be the rate limiting step in anaerobic digestion. Hydrolysis rates have been shown to affect $\mathrm{CH}_{4}$ production; when treating swine waste, hydrolysis rates ranging from 0.07-0.19gCOD/L-day were observed and $\mathrm{CH}_{4}$ production decreased with decreasing hydrolysis rates [21]. 
To increase biogas production, different additives, such as human waste [22], slaughter house waste (blood, rumen, meat) [23 and 24], molasses [23], fats, oils and grease (FOG) [25], crop residues such as cassava peels [26] and coffee hulls [27] and domestic solid wastes [24] have been used. Addition of these organic wastes can increase biogas production if they are readily biodegraded by anaerobic microbes [28]. Careful addition of additives has to be considered [25 and 28]. For example, FOG are mainly composed of long chain fatty acids (LCFA) that can substantially increase biogas production. However, LCFA can lead to decreased biogas production by (1) coating the methanogens' cells which reduces substrate uptake and biogas release and (2) causing sludge flotation and digester foaming leading to washout of anaerobic microbes [29].

Livestock manures also differ in terms of nitrogen, phosphorus and potassium content as illustrated in Table 2 [19 and 30]. The term excreted refers to both the feces and urine before dilution or treatment. Compared with the other manure substrates, swine manure has the highest concentration of nitrogen. To promote growth and carcass leanness, pigs are fed a diet rich in protein [31]. Of this high nitrogen diet, $20 \%$ is excreted as feces and $50 \%$ as urine. The organic nitrogen fraction in the feces is slowly biodegradable, while the fraction in the urine is readily metabolized into TAN (ionized ammonium $\left[\mathrm{NH}_{4}{ }^{+}\right]+$free ammonia $\left[\mathrm{NH}_{3}\right]$ ) via ammonification [32-34]. An increase in temperature can increase the rate of ammonification due to increased microbial growth rates, as discussed below. Increased TAN concentrations may lead to decreased $\mathrm{CH}_{4}$ yields because methanogens are susceptible to TAN inhibition, especially when TAN is in the form of free ammonia. Free ammonia diffuses into the cellular membrane disrupting the microbial $\mathrm{pH}$, energy requirements and enzyme kinetics [35]. Although inhibitory TAN concentrations vary in the literature, generally maintaining TAN concentrations below 
1.5g/L and $\mathrm{pH}$ between 6.8-7.4 will reduce TAN inhibition [6 and 36-38]. TAN concentrations and $\mathrm{pH}$ values measured in tubular digesters in the developing world are shown in Table 1. Even though most digesters have $\mathrm{pH}$ values greater than 7.4 , the digesters operate with TAN concentrations below $1.5 \mathrm{~g} / \mathrm{L}$.

\subsection{Temperature}

Temperature is an important operating parameter because substrate utilization and microbial growth rates are affected by temperature. Microbes transport nutrients in and out of the cell through the cellular membrane. As temperatures decrease, the membrane becomes stiff, causing a decrease in the transport of nutrients [39]. Anaerobic microbes are sensitive to changes in temperature as small as $1-3^{\circ} \mathrm{C}$ [17]. A change in temperature affects the stability of fermenting bacteria. This change in stability may lead to decreased growth rates, $\mathrm{pH}$ changes and decreased $\mathrm{CH}_{4}$ yields [40 and 41]. Common anaerobic digestion temperature settings are psychrophilic (0$\left.15^{\circ} \mathrm{C}\right)$, mesophilic $\left(30-37^{\circ} \mathrm{C}\right)$ and thermophilic $\left(50-60^{\circ} \mathrm{C}\right)$. However, anaerobic microbes can survive at temperatures between 0 and $82^{\circ} \mathrm{C}$ [33]. To achieve thermophilic temperatures, complex heat exchange systems are required and therefore have not been reported in small-scale tubular digester systems. Consequently, most tubular digesters in the developing world operate at ambient temperatures of $15-30^{\circ} \mathrm{C}$ (Table 1). This range is considered to be at the high and low extremes of psychrophilic and mesophilic temperatures respectively [42].

To maintain temperatures that are favorable to anaerobic microbes, tubular digesters were originally designed for use in tropical climates. However, through proper design, operation and maintenance, these systems have also been successfully used in high altitude temperate regions of South America [43 and 44]. As mentioned earlier, one such design is the use of roof shelters, 
which may include a greenhouse. These roofs have been successful in maintaining favorable and stable temperature in tubular digesters even with fluctuations in the ambient temperature.

To establish stable temperatures while treating guinea pig manure using a tubular digester in the Andean Plateau of Peru, Garfí et al. (2011) [13] investigated the effect of two roof shelters (shed roof and dome roof) on biogas production. The digester with the shed roof shelter had significantly lower temperatures and biogas production however, the effluent characteristics were similar in both digesters. Although the authors did not specify why the shed roof had lower temperatures, it is likely that the dome roof has a greater surface area compared to the angled shed roof. Angling the shed roof towards the sun may have also caused this difference.

\subsection{Retention Time}

HRT is the average time the liquid fraction of the waste is in the system and the mean cell residence time, also known as SRT, is the average time the microorganisms are in the system. HRT (day) is approximated by the total volume of the digester $\left(\mathrm{V} ; \mathrm{m}^{3}\right)$ divided by the influent flow rate $\left(\mathrm{Q} ; \mathrm{m}^{3} / \mathrm{day}\right)$ :

$\mathrm{HRT}=\frac{\mathrm{V}}{\mathrm{Q}}$

SRT (day) is measured as the total biomass in the digester $\left(\mathrm{X} ; \mathrm{kg} / \mathrm{m}^{3}\right)$ divided by the biomass wasted per day $\left(\mathrm{X}_{\mathrm{ef}} ; \mathrm{kg} / \mathrm{m}^{3}\right)[33]$ :

$\mathrm{SRT}=\frac{\text { Biomass in the digester }}{\text { Biomass wasted from the digester }}=\frac{\mathrm{VX}}{\mathrm{Q} \mathrm{X}_{\mathrm{ef}}}$

In systems with no solids separation and recycling, SRT is normally equal to the HRT. Although small-scale tubular digesters do not have solids separation or recycling, the SRT in these digesters may not be equal to the HRT. During field studies of tubular digesters in the Monteverde region of Costa Rica, we observed solids accumulation in the digesters, which led to SRTs greater than HRTs. For stable operation of the system, a HRT of at least twice the growth 
rate of the methanogens is required to avoid washout of this group of microorganisms. The design HRT is based on the growth rate of the methanogens because they are the slowest growing anaerobic microorganism [45].

Ambient temperatures and substrate characteristics also affect the required retention time in the digesters. In temperate climates, anaerobic microbes have slower growth rates. This decrease in growth rate requires an increase in digester volume or HRT to allow microbes to utilize substrates. For example, Ferrer et al. (2011) [44] treated cow waste in cold climates and required a HRT of 60-90 days, while Usack et al. (2014) [46], treating cow waste in a tropical region, needed a 3-4 times lower HRT.

Correct estimation of HRT is required because HRT is related to digester volume. Although a decreased digester volume may reduce capital cost, the effluent quality and biogas production may decrease due to insufficient time for microorganisms to degrade the VS. Often, HRT is calculated by dividing the total digester volume; which includes the liquid and gas volume, by the influent flow rate. This is a common error; the actual HRT should be calculated by dividing the working liquid volume by the influent flow rate [11]. Even if the working volume is used to estimate the HRT, the total volume is calculated by multiplying the crosssectional area with the length of the bag, assuming that the working volume will not change. This, however, is not accurate, as the working volume in tubular digesters changes with time due to settling and accumulation of solids [9, 44 and 46].

\subsection{Organic Loading Rate}

If VS are the 'fuel' (substrate) for anaerobic microorganisms, OLR (kgVS/m digester volume/day) can be considered the digester's process capacity and is equal to influent VS concentration $\left(\mathrm{VS}_{\mathrm{i}} ; \mathrm{kgVS} / \mathrm{m}^{3}\right)$ divided by the HRT (day): 
$\mathrm{OLR}=\frac{\mathrm{VS}_{\mathrm{i}}}{\mathrm{HRT}}$

There are two considerations that must be addressed when determining a digester's OLR. First, as mentioned in the previous section, substrate characteristics affect the VS concentration and bioavailability. Second, the digester volume and influent and effluent flow rates. If a tubular digester is fed with an OLR greater than its capacity, acetogenic bacteria produce acetate faster than the methanogens can utilize them, leading to decreased $\mathrm{CH}_{4}$ yields. On the other hand, OLRs lower than the system's capacity do not provide anaerobic microbes enough substrate, leading to low biogas production [21].

Optimal OLRs when treating cow and swine manure anaerobically at mesophilic temperatures are $2.5-3.5 \mathrm{kgVS} / \mathrm{m}^{3}$-day and 3.0-3.5 $\mathrm{kgVS} / \mathrm{m}^{3}$-day respectively [47]. However, it should be noted that these recommended values may not necessarily apply to small-scale tubular digesters. Most of these small-scale systems are operated at OLRs less than $2.0 \mathrm{kgVS} / \mathrm{m}^{3}$-day (Table 1). This could be due to the operation temperatures lower than the mesophilic range (30$37^{\circ} \mathrm{C}$ ) and the lack of mixing. Additionally, due to the simplicity of design it has been observed that loading rates greater than $2.8 \mathrm{kgVS} / \mathrm{m}^{3}$-day are more difficult to manually mix in feed tanks and don't flow easily into the digester [48].

\section{Tubular Digester Benefits}

Use of small-scale tubular digesters results in a number of benefits including: (1) energy benefits: anaerobic digestion is a net-energy producing process. (2) Agricultural benefits: the digester effluent is rich in nutrients and can be used as soil amendment. (3) Environmental benefits by decreasing deforestation and mitigating water pollution from livestock waste. (4) Public health benefits because biogas combustion results in very low air emissions compared 
with combustion of firewood and livestock waste. Lastly, (5) social benefits by helping address gender inequalities.

\subsection{Energy Benefits}

It was observed in Monteverde, Costa Rica that a frequent concern for a household or community with a tubular digester is how much biogas they will be able to use. Although biogas production volume and rates are important, it is essential to compare the production rate with household energy requirements. The quality of biogas produced by small-scale tubular digesters will be considered in the form of heat energy. Electricity is a higher quality of energy compared to heat, but due to economic reasons, biogas from these systems is usually transferred to heat using biogas cook stoves [49 and 50]. The biogas production rate is equal to the daily biogas volume produced $\left(\mathrm{m}^{3}{ }_{\text {biogas }} /\right.$ day) divided by the volume of the digester:

Biogas Production Rate $=\frac{\text { Daily biogas volume produced }}{V}$

Biogas yield $\left(\mathrm{m}^{3}\right.$ digester $\left./ \mathrm{kgVS}_{\mathrm{added}}\right)$ is dependent on the biogas production and OLR and expressed mathematically as:

Biogas Yield $=\frac{\text { Biogas Production Rate }}{\text { OLR }}$

Potential biogas and $\mathrm{CH}_{4}$ yields produced for specific animals are summarized in Table 3. As mentioned previously, only a certain percentage of the influent VS are utilized in the anaerobic process depending on the animal. The volume of biogas and $\mathrm{CH}_{4}$ produced per animal per day can be approximated assuming animal specific biogas yields from the literature [47]. This potential $\mathrm{CH}_{4}$ volume per animal per day can also be expressed as a heating value. Pure $\mathrm{CH}_{4}$ has a heating energy value of $11.2-18.6 \mathrm{MJ} / \mathrm{m}^{3} \mathrm{CH}_{4}$ [51]. Biogas from tubular digesters has $\mathrm{CH}_{4}$ contents ranging from $21-76 \%$ (Table 1), resulting in potential heating energy values between 2.35 to $14.1 \mathrm{MJ} / \mathrm{m}^{3} \mathrm{CH}_{4}$. Potential heating energy production rates per day for various animal 
wastes are calculated in Table 3. The material of the cooking vessel, food being cooked and ambient temperature and pressure affect the heating energy demands. To illustrate if the potential heating energy production rates (Table 3) will meet a household's demands, the total heating energy required was calculated (Table 4). For this analysis it was assumed that water, rice, beans, potatoes and eggs, foods commonly eaten in the developing world, were boiled from 20 to $100^{\circ} \mathrm{C}$ in copper, aluminum, stainless steel, cast iron and clay vessels.

To better illustrate the heating energy benefits of the biogas produced by tubular digesters, an example of a household that typically cooks rice and beans and owns sows will be used. A $200 \mathrm{~kg}$ sow can produce an average of $8.1 \mathrm{~kg}$ of excreta per day containing $0.74 \mathrm{~kg}$ VS [19]. If $49 \%$ of the VS are utilized and the average biogas yields for sow waste are 0.13-0.55 $\mathrm{m}^{3}$ biogas/kgVS [47], the volume of biogas produced per animal can be approximately 0.03$0.28 \mathrm{~m}^{3}$ biogas/day-animal. Assuming a $\mathrm{CH}_{4}$ content of $60 \%$, this $200 \mathrm{~kg}$ sow can produce an average heating energy value of $1636 \mathrm{~kJ} / \mathrm{day}$. If a safety factor of $40 \%$ is included to account for the cook stove's combustion efficiency, the heating energy value would be $654 \mathrm{~kJ} /$ animal-day. If a household wanted to boil $0.5 \mathrm{~kg}$ of rice in a $0.5 \mathrm{~kg}$ stainless steel cooking vessel in a $20^{\circ} \mathrm{C}$ room at sea level, the total heat energy required would be $355 \mathrm{~kJ}$. To boil $0.5 \mathrm{~kg}$ of beans in the same stainless steel vessel, the heat energy required is $234 \mathrm{~kJ}$. The total heat energy required by this household to cook a meal of $0.5 \mathrm{~kg}$ of rice and $0.5 \mathrm{~kg}$ of beans is $589 \mathrm{~kJ}$. In this hypothetical example, the tubular digester operated with one sow is producing enough biogas to meet the household's cooking energy demands. This further justifies what was observed in households using biogas from tubular digesters in Monteverde, Costa Rica. Biogas produced from 2-4 pigs was enough for 3-4 hours of cooking for a household of 4-5 people. The households were also 
saving approximately $\$ 20$ per month compared to other households that used propane for cooking.

\subsection{Agricultural Benefits}

Anaerobic digestion effluent contains primary nutrients, nitrogen and phosphorus, and secondary nutrients, potassium, calcium and magnesium, and micro-nutrients, zinc, copper and iron. The roles of nitrogen and phosphorus during crop production are illustrated in Table 5. Only the primary nutrients will be discussed in this review. Nutrient rich effluent can be used as a soil amendment to improve plant growth. This is an environmentally and economically attractive alternative compared to the use of mineral fertilizers, the production of which consumes about $1.2 \%$ of the world's energy and is responsible for about $1.2 \%$ of the world's GHG emissions [52]. Effluents from anaerobic digesters also contain more inorganic nutrients that are available to plants compared to raw waste due to mineralization of organics during digestion [53]. Agricultural benefits therefore encompass agronomic benefits (increased crop yield due to anaerobic digester effluent application) and economic benefits (monetary gain/profit). It is important to understand the balance of benefits to the people using the smallscale tubular digesters, the soil and plants [54 and 55].

Agronomic benefits mainly refer to the use of the effluent to improve the soil fertility leading to increased crop yields. Anaerobic effluents from treated livestock waste not only provide nutrients to the soil but also organic matter. Addition of organic matter from the effluent strengthens soil structure by promoting aggregation of soil granules by soil microorganisms. Increase of organic carbon lowers the carbon nitrogen $(\mathrm{C} / \mathrm{N})$ ratio of the soil [56]. Application of stabilized manure has also been shown to increase soil's total porosity by about $24 \%$ compared to mineral fertilizers [57]. This is due to increased microbial dehydrogenase activity (enzymatic 
removal of hydrogen from the soil), which is catalyzed by the organic matter in the effluent [57]. If applied before planting, effluents have been shown to assist in crop disease control. This phenomenon occurs when substrates, such as carbohydrates and lignin, in the effluent are utilized by the microbes in the soil. Through competition, antagonism and predation, biological disease control is achieved [58].

Nitrification is a naturally occurring biological process that occurs when TAN is applied to land. During the nitrification process, hydrogen ions are formed that contribute to soil acidity. At low $\mathrm{pH}$ levels $(<5.5)$, the solubility of toxins, such as aluminum (Al) and manganese (Mn) naturally found in clay soils, increases. Uptake of $\mathrm{Al}$ and $\mathrm{Mn}$ by plants results in root deterioration, discoloration, low yields and lack of growth. Soils therefore need buffering capacity to maintain the $\mathrm{pH}$ between 6.0 and 7.0. This buffering capacity can be provided by effluent with a neutral pH [59]. Garfí et al. (2011) [13] found a significant difference in potato yields between soil fertilized with effluent from a tubular digester treating guinea pig waste and compost. The author noted a $27.5 \%$ increase in potato yield and attributed it to the nutrients present in the effluent. Chantigny et al. (2008) [55] also credited micronutrient availability in increasing corn yield when comparing clay and loam soils fertilized with either mineral fertilizer or anaerobically digested swine effluent. In Cambodia for example, effluent from a tubular digester treating swine waste was used to fertilize mulberry plants. In this study the biomass yield increased due to the increased nitrogen and organic matter in the soil. This same study also reported a linear increase in the protein content of the mulberry leaves [121].

To use effluent as a soil amendment, the fate of the nutrients during anaerobic digestion [60] has to be evaluated. During anaerobic digestion, organic matter in the waste is degraded to produce $\mathrm{CH}_{4}$ and $\mathrm{CO}_{2}$, thus lowering the effluent carbon to nitrogen $(\mathrm{C} / \mathrm{N})$ ratio and solids 
concentration. Garfí et al. (2011) [13] reported that when treating guinea pig waste in Peru, the $\mathrm{C} / \mathrm{N}$ ratio decreased from 17.0 in raw waste to 2.9 in the effluent. This reduced $\mathrm{C} / \mathrm{N}$ ratio is favorable because it reduces the competition for nitrogen between soil microorganisms and plants. TAN produced during anaerobic digestion can either be utilized by microorganisms for growth, form precipitates such as struvite or ammonium carbonate, and/or volatilize [61]. In Sudan, Mubarak et al. (2010) [62] also concluded that mineralization of nitrogen in cow, pig, goat, pigeon and camel manure increased soil quality. Mineralization also assists in solids reduction; lower solids concentrations decrease effluent viscosity, which increases permeation of inorganic nitrogen into the soil for faster plant uptake [60].

Soils require both nitrogen and phosphorus; however, the natural supply of phosphorus for plants is usually low [61]. Anaerobic digestion of livestock waste has been shown to increase the concentration of soluble phosphorus that can be easily taken up by plants, which increases the nitrogen to phosphorus (N/P) ratio [60]. Mineralization of nitrogen, phosphorus and magnesium and increased $\mathrm{pH}$ during anaerobic digestion can lead to struvite precipitation (Equation 7), especially while treating swine waste, due to high concentrations of TAN and orthophosphates present [63].

$\mathrm{Mg}^{2+}+\mathrm{NH}_{4}^{+}+\mathrm{H}_{2} \mathrm{PO}_{4}^{-}+6 \mathrm{H}_{2} \mathrm{O} \rightarrow \mathrm{MgNH}_{4} \mathrm{PO}_{4} \cdot 6 \mathrm{H}_{2} \mathrm{O}+2 \mathrm{H}^{+}$

Unfortunately, struvite precipitation during anaerobic digestion can be a problem due to fouling and clogging pipes [64], especially in tubular digesters that are already prone to solids accumulation and clogging due to their design.

More than $70 \%$ of people living in rural regions in the developing world depend on agriculture [65]. Increased crop yield from using digester effluent may mean more crops available for sale. In Nepal for example, households observed an increase in crop production of 
up to $68 \%$ when digester effluent was used [66]. An economic analysis is important to link agronomic and economic benefits. Costs include fixed costs such the construction of the digester, pipes, biogas stove and tractor depending on the farm size and operational costs include labor, maintenance, and reduced cost of fertilizer and cooking fuel [67]. Mineral fertilizer can cost about \$76.3-313.7/ha (Oklahoma, USA) which accounts for 39-85\% of the cost depending on application rates and requirements. Digester effluent can cost about $\$ 29.8-85.3 /$ ha also depending on the application rate. Digester construction, labor and repair costs account for most of the cost depending on type of manure and maintenance of the digester [67]. To reduce the labor cost for example, communities in Sudan constructed their own digesters [68]. Since effluents have higher crop yields and significantly lower total costs, the economic return is more attractive. There is little published literature on the economic benefits of tubular digesters; therefore, more research should be carried out in this topic.

\subsection{Environmental Benefits}

Environmental benefits that will be discussed in this section are reduction of deforestation and water pollution from livestock waste. It is important to understand how deforestation contributes to climate change and how tubular digester can be used to mitigate this issue. Understanding the link between mismanagement of livestock waste and water pollution is also critical in improving water sources for drinking, recreation, agriculture and fishing.

\subsubsection{Deforestation}

Deforestation is one of the causes of climate change. Deforestation accounts for about $20 \%$ of GHG emissions from biofuel production and from expansion of land for agriculture and shelter. Carbon that is stored in the forest biomass is released during combustion and wood degradation [69 and 70]. Trees are also beneficial because they absorb $\mathrm{CO}_{2}$ from the atmosphere. 
The accumulation of GHG leads to global temperature rise, which affects climate and hydrology. Decreased precipitation and water infiltration result in soil erosion, which pollutes surface water, increases flooding, decreases biodiversity and soil quality, and decreases crop yield [71].

Unfortunately, poor communities in the developing world are the most vulnerable to deforestation and climate change effects [69]. For example, in Haiti, population increase has led to increased demand for firewood. This dependence is one of the reasons that have led to severe deforestation leaving this country with only $1-2 \%$ of vegetation cover [72]. In addition, water pollution from soil runoff and low groundwater recharge has led to water shortages [73].

Installation of biogas systems has been shown to decrease dependence on firewood by providing an alternative fuel source. In Nepal, Katuwal and Bohara (2009) [66] observed a 53\% decrease in firewood use after installing biogas systems. In Sub-Saharan Africa, use of biogas from anaerobic systems is estimated to decrease deforestation by $26 \%$ by 2030 [74]. Although tubular digesters are beneficial in mitigating deforestation, a lack of knowledge and education on the link between climate change, deforestation and firewood use prevent further adaptation of the technology. This is because many communities in the developing world consider firewood as a "free" fuel [75].

\subsubsection{Water pollution from Livestock Waste}

Lack of proper livestock waste management leads to runoff of pollutants into surface waters and groundwater pollution. Untreated livestock waste contains a number of pollutants of concern that are summarized in Table 6. Use of a tubular digester can mitigate some of these water pollutants of concern. During anaerobic digestion, both particulate and dissolved organic matter in the waste is degraded to produce biogas. Lansing et al. (2008) [9] observed biochemical oxygen demand (BOD) and total suspended solids removals of 79 and $86 \%$, 
respectively, during treatment of swine waste in Costa Rica. Usack et al. (2014) [46] observed chemical oxygen demand (COD) and total solids removals of approximately 65 and 31\%, respectively, during treatment of dairy waste in Indonesia. These results show that the tubular digester systems can be beneficial in reducing water pollution. Although the process of anaerobic digestion does not reduce the concentration of nitrogen and phosphorus, the waste is stabilized and can be used as a fertilizer, as mentioned previously [57]. However, it is recommended that farmers implement best management practices to control runoff. Some of these practices include: (1) a vegetation filter strip between the fields and water bodies, (2) a water and sediment drainage basin that receives agricultural runoff, (3) constructed wetlands and (4) duckweed and fish ponds [76].

According to WHO, Cryptosporidium, Giardia, Campylobacter, Salmonella and E. coli O157 are the main zoonotic pathogens that cause illness to humans. Livestock waste can contain high loads of these pathogens, especially protozoan parasites [77]. There is limited research on the inactivation of these pathogens during livestock waste treatment in tubular digesters in the developing world. Garfi et al. (2011) [13] measured total coliforms and E.coli while treating guinea-pig waste (Table 1). In this study, negligible removal of these pathogens was observed. Masse et al. (2011) [78] investigated the fate of total and fecal coliforms, E. coli, Salmonella, Campylobacter spp., and $Y$. enterocolitica in a $24^{\circ} \mathrm{C}$ farm scale sequencing batch anaerobic reactor operated at HRTs of 7 and 14 days. At both HRT values, a significant decrease of these pathogens was observed. Differences in results from Garfi et al. (2011) [13] and Masse et al. (2011) [78] are unknown; indicating that more research is needed on how the design, operation and maintenance of tubular digesters affect the fate of pathogens. Cote et al. (2006) [79] treated swine waste in a $20^{\circ} \mathrm{C}$ anaerobic sequencing batch reactor with a 20 day SRT and observed level 
of Salmonella, Cryptosporidium oocysts and Giardia cysts below the detection limits in the effluent. This study did not explicitly indicate an inactivation mechanism; instead they mentioned that there was removal of pathogens, which may be due to a physical removal process. The study also did not analyze the viability of Cryptosporidium and Giardia (oo)cysts which is vital in determining their infectivity. Therefore, more research is needed to determine the viability of Cryptosporidium and Giardia (oo)cysts during livestock waste treatment in tubular digesters.

\subsection{Social Benefits}

Social benefits discussed in this review are in regards to increasing gender equality. Decreased incidence of disease (discussed in Section 4.5) and decreased time demands for women are positive outcomes of implementation of tubular digesters. Due to cultural and social roles, women provide unpaid household labor by providing human energy in survival activities. Survival activities include; collection of firewood, water collection and food preparation. This human energy is undervalued when nations report their economic contributions. For example, in India, women spend approximately nine hours per day on survival activities, while men spend five hours per day [80]. According to the International Labor Office, firewood collection is the most time-consuming survival activity for women in rural villages in Peru, Ghana, Mozambique, India and Indonesia [81]. In rural Nepal, women who utilize firewood as cooking fuel spent approximately four hours per day searching for firewood, usually over long distances [66]. Once anaerobic digestion systems were installed, 33\% of the women spent their time participating in social and community activities. This saved the women up to three hours each day, time that was otherwise spent searching for firewood [66 and 82]. In same study, the authors found that the 111,000 anaerobic digester systems installed translated to 35,000 woman hours per year [82]. 
Time saved from fuel collection has been shown to be used in economic activities, including beer brewing in Burkina Faso and Tanzania, bakeries in Kenya and Peru, shea butter production in the Sahel region of Africa, soap making in Bangladesh, tea shops in Nepal and pottery making [80].

\subsection{Public Health Benefits}

Millions of children die in the developing world due to exposure to indoor air pollution. Over reliance on firewood, coal and animal waste as a source of fuel leads to deteriorating indoor air quality from the emissions of particulate matter, carbon monoxide, sulfur dioxide, oxides of nitrogen and many other harmful byproducts from combustion of biomass. In Sub-Saharan Africa, firewood is the predominant fuel source, especially in the rural places. In Tanzania, Uganda, Senegal, Zambia, Malawi, and Kenya, 96, 91, 89, 88, 96 and 88\%, of rural households respectively, rely on firewood as their main fuel source [75]. Women and children under the age of 5 are especially affected by indoor air pollution [83]. Indoor air pollution leads to acute lower and upper respiratory infections, chronic pulmonary disease, leading to lung fibroids and bronchiectasis, asthma, infant mortality, low birth weight and eye infections [83 through 85]. Bonte (1974) [86] showed that there were more deaths and hospitalizations of people in Kenya with respiratory complications compared to those caused by malaria. However, very little attention has been paid to reducing the causes of respiratory diseases in the developing world [87].

Programs targeted at reducing or curbing the sources of indoor air pollution have shown been successful at reducing the frequency of respiratory diseases in Brazil [88]. Such programs rely heavily on improving energy sources. As of $2002,81 \%$ of the population in Nepal used solid biofuels, leading to 4,820 deaths due to acute lower respiratory infections (ALRI) for children 
under the age of 5 and 2,680 deaths due to chronic obstructive pulmonary disease (COPD) for people older than 30 years [89]. To assist with this situation, the Biogas Support Program (BSPNepal) organization was formed in 2003. Biogas systems were installed and the public health impacts of biogas systems were analyzed using the Biogas User Survey 2007/2008. Eye infections, respiratory disease, coughing and headaches were decreased in women, men and children who used biogas. The health improvements were especially significant for women, who reported a $40 \%$ reduction in eye infections and headaches and a $25 \%$ reduction in respiratory disease and coughing [66].

\section{$5 \quad$ Policies Promoting Anaerobic Digestion of Livestock Waste}

This section provides an overview of policies related to various types of small-scale biogas systems, rather than focusing only on tubular anaerobic digestion. Although small-scale biogas systems have been adopted in many developing countries, financial obstacles, such as lack of capital and credit, have prevented widespread adoption of the technology [90]. Lack of local demand for biogas as an energy source due to other less expensive energy sources also decreases adoption of tubular digesters. For example, in spite of India's large livestock waste production, there is a lack of demand for its collection and transformation into useful energy [91]. Therefore, to overcome these obstacles, developing country communities, national and

local governments, funding agencies and development organizations need to provide funding and technical assistance for technology transfer to be successful. This includes:

1. Promotion of biogas as a renewable energy source on a country level,

2. Encouraging country-driven efforts and access to funding,

3. A shift from project-driven to programmatic-driven approaches and 
4. Providing activities that are relevant to climate change and the millennium development goals [91].

A summary of the agencies promoting household-scale anaerobic digestion, types of digesters promoted, financial and/or business models used and current market trends for countries in Africa, Asia and Latin America are provided in Tables 7, 8, and 9, respectively. In Africa and Asia, funds for digester implementation have mainly been dispersed from national financial ministries to provincial, municipal and township finance offices and finally to local economic cooperatives that provide loans to farmers or offer subsidies to cover capital costs. These programs have resulted in increased adoption of biogas systems; however, there is still a need for increased monitoring of rural economic growth and water quality improvements as well as systematic education on the benefits of the technology. Such programs will increase demand by users and provide justification for developing revolving funds by banks and governments [92, 93, 107 and 108]. In contrast, comprehensive national biogas programs are lacking in Latin America and the Caribbean. In these countries, biogas systems have mainly been implemented by local NGOs and educational institutions. There is a need for a marketing and business model in Latin America that ensures that funds are accessible to farmers and outlines the roles and responsibilities of NGOs, development agencies, banks and the government [112].

Biogas programs have been successfully integrated into programs promoting sustainable agriculture, increased food and energy security, economic growth and environmental protection for rural farming families, as shown in Figure 4. In Vietnam, tubular digesters are installed as part of the VACB model, which includes a garden (V), animal farm (A), fish pond (C) and biogas system (B) [94]. Studies in Vietnam and Laos have shown successful implementation of this VACB model to promote food security. In Laos, Nouanthavong and Preston [122] reported 
that tilapia that was fed with duckweed fertilized with tubular digester effluent had a four-fold weight gain compared with tilapia that was fed with unfertilized duckweed. In Vietnam, Tu et al. [123] observed that $72 \mathrm{mg} \mathrm{N} / \mathrm{L}$ (12\% digester effluent to $88 \%$ water) promoted optimal duckweed growth and protein content as a feed for animals, such as ducks. In Cambodia, latrinebiodigesters have become popular, which has resulted in increased access to sanitation in rural communities. Households can also earn additional revenue through the sale of verified carbon offsets as part of the Cambodia climate change initiative [113]. In Kenya, women have been the main adopters of small-scale biogas systems and have increased their revenues by receiving training on masonry and sale of stonework and bricks for digester construction [106]. A study in Laos showed that families without tubular digesters were interested in installing these systems due to income from pig rearing and health benefits they observed from the reduced air pollution in users' homes. However, those interested individuals needed financial assistance with vaccinating and feeding the pigs [114]. Therefore, national biogas programs should also account for other costs associated with installation, operation and maintenance of biogas systems.

Unfortunately, government policies, regulations and collaboration with organizations do not necessarily lead to successful implementation of biogas technologies. For example, the Haitian Environment Ministry is collaborating with the United States Senate Committee on Foreign Relations to finance Waste to Energy (WTE) projects [95]. However, the widespread lack of education on the dangers of deforestation, corruption, political instability, lack of knowledge of the law, lack of accountability by the public sector and poor infrastructure make financing WTE projects difficult. The National Renewable Energy Laboratory (NREL) is also working in Haiti on the implementation of biogas systems in the country; however, the process has been slow [95]. This scenario is similar in other developing countries. More education and 
regular monitoring of environmental regulations and laws is needed to make financing of these projects easier by public and private sectors.

\section{Conclusions and Recommendations}

Tubular digesters are an efficient livestock waste treatment technology that generates biogas and a nutrient rich effluent. For a tubular digester to meet a household's or community's cooking energy needs, the substrate characteristics, temperature in the digester, OLR and retention times have to be understood for proper design of the system and to reduce operational problems. Good performance of the tubular digester can then lead to energy benefits, agricultural benefits, environmental benefits from decreasing dependence on biomass for fuel and from decreasing water pollution, public health benefits by providing a clean burning fuel and social benefits by promoting gender equality. For communities to enjoy these benefits, several developing countries have implemented policies that educate and curb financial obstacles that limit widespread adoption of anaerobic digestion technologies of livestock waste. These policies can be used as examples for other developing countries governments seeking to improve the quality of life for their citizens.

\section{Acknowledgements}

This research was supported by the National Science Foundation under Grant Numbers 1243510 and 0965743 and the U.S. Peace Corps. Any opinions, findings, and conclusions or recommendations expressed in this material are those of the authors and do not necessarily reflect the views of the National Science Foundation. 


\section{References}

[1] Westerman PW. Biogas anaerobic digester considerations for swine farms in North Carolina. Raleigh, NC: N.C. Cooperative Extension Service; 2008.

[2] Ferrer I, Gamiz M, Almeida M, Ruiz A. Pilot project of biogas production from pig manure and urine mixture at ambient temperature in Ventanilla (Lima, Peru). Waste Management 2009;29(1): 168-73. doi: 10.1016/j.wasman.2008.02.014.

[3] Lüer M, editor. Installation manual for low-cost polyethylene tube digesters; 2010. Retrieved November 26, 2012 from https://energypedia.info/images/1/19/Low_cost_polyethylene_tube_installation.pdf

[4] Ocwieja SM. Life cycle thinking assessment applied to three biogas projects in central Uganda [thesis]. Houghton (MI): Michigan Technological University; 2010.

[5] Kossmann W, Pönitz U, Habermehl S, Hörz T, Krämer P, Klingler B, Euler H. Biogas application and product development. Biogas digest (volume II). Germany: GTZ; 1999.

[6] Kinyua MN. Effect of solids retention time on the denitrification potential of anaerobically digested swine waste [thesis]. Tampa (FL): University of South Florida; 2013.

[7] Botero RB, Preston TR. Biodigestor de bajo costo para la produccion de combustible y fertilizante a partir de excretas; 1987. Retrieved August 10, 2014 from http://www.utafoundation.org/publications/botero\&preston.pdf.

[8] An, XB, Rodriguez, J, Sarwatt, SV, Preston, TR, Dolberg, F. Installation and performance of low cost polyethylene tube biodigesters on small-scale farms. World Anim. Rev. 1997; 88. Retrieved November 19, 2014 from http://www.fao.org/docrep/w5256t/W5256t06.htm\#TopOfPage. 
[9] Lansing S, Víquezb J, Martínezc H, Boterod R, Martine J. Quantifying electricity generation and waste transformations in a low-cost, plug-flow anaerobic digestion system. Ecological Engineering 2008;34: 332-48. doi:10.1016/j.ecoleng.2008.09.002.

[10] Eaton AB. The role of small-scale biodigesters in the energy, health, and climate change baseline in Mexico [thesis]. Arcata (CA): Humboldt State University; 2009.

[11] Martí-Herrero J. Reduced hydraulic retention times in low-cost tubular digesters: Two issues. Biomass and Bioenergy 2011;35: 4481-4. doi:10.1016/j.biombioe.2011.07.020.

[12] Rajendran K, Aslanzadeh S, Taherzadeh MJ. Household biogas digesters - A review. Energies 2012;5: 2911-42. doi:10.3390/en5082911.

[13] Garfi M, Ferrer-Martí L, Villegas V, Ferrer I. Psychrophilic anaerobic digestion of guinea pig manure in low-cost tubular digesters at high altitude. Bioresource Technology 2011;102: 6356-9. doi:10.1016/j.biortech.2011.03.004.

[14] EPA. Sulfur Dioxide: Health; 2014. Retrieved November 18, 2014 from http://www.epa.gov/air/sulfurdioxide/health.html.

[15] Magomnang ASM, Villanueva EP, editors. Proceedings of the International Conference on Agricultural, Environmental and Biological Sciences (AEBS-2014). Removal of Hydrogen Sulfide from Biogas using Dry Desulfurization Systems; 2014 April 24-25; Phuket, Thailand. Retrieved October 21, 2014 from http://iicbe.org/siteadmin/upload/3607C414016.pdf.

[16] Rowse LE. Design of Small Scale Anaerobic Digesters for Application in Rural Developing Countries [thesis]. Tampa (FL): University of South Florida; 2012. 
[17] Gerardi MH. The Microbiology of Anaerobic Digesters. $1^{\text {st }}$ ed. Hoboken, NJ: John Wiley and Sons, Inc.; 2003.

[18] Converti A, Drago F, Ghiazza G, Borghi MD, Macchiavello A. Co-digestion of Municipal Sewage Sludges and Pre-hydrolysed Woody Agricultural Wastes. J. Chemical Technology and Biotechnology 1997;69(2): 231-9.

[19] USDA, Natural Resources Conservation Service. Agricultural waste characteristics. Part 651, Agricultural Waste Management Field Handbook; 2008. Retrieved November 21, 2014 from http://directives.sc.egov.usda.gov/OpenNonWebContent.aspx? content=31475.wba.

[20] Andrén O, Kirchmann H, Petterson O. Reaping the benefits of cropping experiments. Nature 1999;399(6731): 14-14. doi:10.1038/19845.

[21] Kinyua MN, Cunningham J, Ergas SJ. Effect of Solids Retention Time on the Use of Anaerobically Digested Swine Waste as a Substrate for Denitrification, Bioresource Technology 2014, 162; 14-20.

[22] Galvin C. Embodied energy and carbon footprint of household latrines in rural Peru: The impact of integrating resource recovery [thesis]. Tampa (FL): University of South Florida; 2013.

[23] Guyana Energy Agency. Bio-digester information and construction manual for small farmers; 2012. Retrieved on October 24, 2014 from http://www.gea.gov.gy/downloads/Biodigester-Manual.pdf. 
[24] Vögeli Y, Lohri CR, Gallardo A, Diener S, Christian S. Anaerobic Digestion of Biowaste in Developing Countries: Practical Information and Case Studies. Dübendorf, Switzerland: Swiss Federal Institute of Aquatic Science and Technology (Eawag); 2014.

[25] Lansing S, Martin JF, Botero RB, da Silva TN, da Silva ED. Methane production in lowcost, unheated, plug-flow digesters treating swine manure and used cooking grease. Bioresource Technology 2010;101(12): 4362-70. doi:10.1016/j.biortech.2010.01.100.

[26] Adeyanju AA. Effect of seeding wood-ash on biogas production using pig waste and cassava peels. J. of Engineering and Appl. Sciences 2008;3(3): 242-5.

[27] Kivaisi AK. Pretreatment of robusta coffee hulls and co-digestion with cow-dung for enhanced anaerobic digestion. Tanzania Journal of Science 2002;28(2): 1-10. http://dx.doi.org/10.4314/tjs.v28i2.18349.

[28] Cirne DG, Paloumeta X, Björnssona L, Alvesb MM, Mattiassona B. Anaerobic digestion of lipid-rich waste_Effects of lipid concentration. Renew. Energy 2007;32(6): 965-75. doi:10.1016/j.renene.2006.04.003.

[29] Long JH, Aziz TN, de los Reyes III F, Ducoste JJ. Anaerobic co-digestion of fat, oil, and grease (FOG): A review of gas production and process limitations. Process Saf. and Environmental Protection 2012;90(3): 231-45. doi:10.1016/j.psep.2011.10.001.

[30] Choi E. Piggery waste management: Towards a sustainable future. London: IWA Publishing; 2007.

[31] Kerr BJ, Easter RA. Effect of feeding reduced protein, amino acid-supplemented diets on nitrogen and energy balance in grower pigs. J. Anim. Science 1995;73:3000-8. 
[32] Canh TT, Aarnink AJA, Schutte JB, Sutton A, Langhout DJ, Verstegen MWA. Dietary protein affects nitrogen excretion and ammonia emission from slurry of growingfinishing pigs. Livest. Production Science 1998;56(3): 181-91. doi:10.1016/S03016226(98)00156-0.

[33] Tchobanoglous G, Burton FL, Stensel HD. Wastewater Engineering: Treatment and Reuse. 4th ed. Boston, MA: McGraw-Hill; 2003.

[34] Im J, Gi K. Effect of anaerobic digestion on the high rate of nitritation, treating piggery wastewater. J. of Environmental Sciences-China 2011;23(11): 1787-93. doi: 10.1016/S1001-0742(10)60649-3.

[35] Wittmann C, Zeng AP, Deckwer W D. Growth inhibition by ammonia and use of a pHcontrolled feeding strategy for the effective cultivation of mycobacterium chlorophenolicum. Appl. Microbiology and Biotechnology 1995;44: 519-25.

[36] Angelidaki I, Ahring BK. Thermophilic anaerobic digestion of livestock waste: The effect of ammonia. Appl. Microbiology and Biotechnology 1993;38: 560-4.

[37] Hansen KH, Angelidaki I, Ahring BK. Anaerobic digestion of swine manure: Inhibition by ammonia. Water Res. 1998;32(1): 5-12. doi: 10.1016/S0043-1354(97)00201-7.

[38] Kaparaju P, Rintala J. Anaerobic co-digestion of potato tuber and its industrial by-products with pig manure. Resources Conservation and Recycling 2005;43(2): 175-88. doi: 10.1016/j.resconrec.2004.06.001.

[39] Nedwell DB. Effect of low temperature on microbial growth: lowered affinity for substrates limits growth at low temperature. FEMS Microbiology Ecology 1999;30(2): 101-11. doi: 10.1111/j.1574-6941.1999.tb00639.x. 
[40] Visser A, Gao Y, Lettinga G. Effects of short-term temperature increases on the mesophilic anaerobic breakdown of sulfate containing synthetic wastewater. Water Res. 1993;27(4): 541-50. doi:10.1016/0043-1354(93)90163-C.

[41] Dohányos M, Zábranská J. Anaerobic digestion. In: Spinosa L, Vesilind PA, editors. Sludge into Biosolids: Processing, Disposal, and Utilization. London, UK: IWA Publishing; 2001. p. 223-41.

[42] Amani T, Nosrati M, Sreekrishnan TR. Anaerobic digestion from the viewpoint of microbiological, chemical, and operational aspects - A review. Environmental Reviews 2010;18: 255-78. doi: 10.1139/A10-011.

[43] Alvarez R, Lidén G. Low temperature anaerobic digestion of mixtures of llama, cow and sheep manure for improved methane production. Biomass and Bioenergy 2009;33: 52733. doi:10.1016/j.biombioe.2008.08.012.

[44] Ferrer I, Garfí M, Uggetti E, Ferrer-Martí L, Calderon A, Velo E. Biogas production in lowcost household digesters at the Peruvian Andes. Biomass and Bioenergy 2011;35: 166874. doi:10.1016/j.biombioe.2010.12.036.

[45] Shin SG, Yoo S, Hwang K, Song M, Kim W, Han G, Hwang S. Dynamics of transitional acidogenic community along with methanogenic population during anaerobic digestion of swine wastewater. Process Biochemistry 2011;46(8): 1607-13. doi:10.1016/j.procbio.2011.05.001.

[46] Usack JG, Wiratni W, Angenent LT. Improved Design of Anaerobic Digesters for Household Biogas Production in Indonesia: One Cow, One Digester, and One Hour of 
Cooking per Day. The Scientific World J. 2014;(2014): 1-8. http://dx.doi.org/10.1155/2014/318054.

[47] Burton CH, Turner C. Manure management: Treatment strategies for sustainable agriculture. $2^{\text {nd }}$ ed. Bedford, UK: Silsoe Research Institute; 2003.

[48] An XB, Preston TR. Gas production from pig manure fed at different loading rates to polyethylene tubular biodigesters. Livest. Res. for Rural Development 1999;11(1): 1-8.

[49] Bond T, Templeton MR. History and future of domestic biogas plants in the developing world. Energy for Sustainable Development 2011;15: 347-54. doi:10.1016/j.esd.2011.09.003.

[50] Rutz D, Mergner R, Janssen R. Sustainable heat use of biogas plants- A Handbook. Munich, Germany: WIP Renewable Energies; 2012.

[51] Speight JG. The Chemistry and Technology of Coal. $2^{\text {nd }}$ ed. New York: Marcel Dekker Inc.; 1994.

[52] Kongshaug G, editor. Energy consumption and greenhouse gas emissions in fertilizer production. Proceedings of the International Fertilizer Industry Association Technical Conference; 1998 Sep 28- Oct 1; Marrakech, Morocco; 1998.

[53] Arthurson V. Closing the Global Energy and Nutrient Cycles through Application of Biogas Residue to Agricultural Land - Potential Benefits and Drawback. Energies 2009;2(2): 226-42. doi:10.3390/en20200226.

[54] Adeli A, Varco JJ, Sistani KR, Rowe DE. Effects of Swine Lagoon Effluent Relative to Commercial Fertilizer Applications on Warm-Season Forage Nutritive Value. Agronomy J. 2005;97: 408-17. 
[55] Chantigny MH, Angers DA, Bélanger G, Rochette P, Eriksen-Hamel N, Bittman S, Gasser MO. Yield and Nutrient Export of Grain Corn Fertilized with Raw and Treated Liquid Swine Manure. Agronomy J. 2008;100(5): 1303. doi:10.2134/agronj2007.0361.

[56] Bronick CJ, Lal R. Soil structure and management: A review. Geoderma 2005;124(1-2): 322. doi:10.1016/j.geoderma.2004.03.005.

[57] Marinari S, Masciandaro G, Ceccanti B, Grego S. Influence of organic and mineral fertilisers on soil biological and physical properties. Bioresource Technology 2000;72: 917.

[58] Hoitink HAJ, Boehm MJ. Biocontrol within the context of soil microbial communities: A substrate-dependent phenomenon. Annual Rev. of Phytopathology 1999;37: 427-46.

[59] Zhang H, Raun B. Oklahoma Soil Fertility Handbook. 6th ed. Stillwater, OK: Department of Plant and Soil Sciences, Oklahoma State University; 2006.

[60] Massé DI, Croteau F, Masse L. The fate of crop nutrients during digestion of swine manure in psychrophilic anaerobic sequencing batch reactors. Bioresource Technology 2007;98(15): 2819-23. doi:10.1016/j.biortech.2006.07.040.

[61] Möller K, Müller T. Effects of anaerobic digestion on digestate nutrient availability and crop growth: A review. Engineering in Life Sciences 2012;12(3): 242-57. doi:10.1002/elsc.201100085.

[62] Mubarak AR, Gali EAM, Mohamed AG, Steffens D, Awadelkarim AH. Nitrogen Mineralization from Five Manures as Influenced by Chemical Composition and Soil Type. Communications in Soil Science and Plant Analysis 2010;41(16): 1903-20. doi:10.1080/00103624.2010.495802. 
[63] Loewenthal RE, Kornmuller URC, vanHeerden EP. Modeling struvite precipitation in anaerobic treatment systems. Water Science and Technology 1995;30(12): 107-16.

[64] Marti N, Bouzas A, Seco A, Ferrer J. Struvite precipitation assessment in anaerobic digestion processes. Chemical Engineering Journal 2008;141(1-3): 67-74. doi: 10.1016/j.cej.2007.10.023.

[65] International Fund for Agricultural Development (IFAD). Rural Poverty Report: New realities, new challenges: new opportunities for tomorrow's generation; 2010. Retrieved December 9, 2014 from http://www.ifad.org/rpr2011/report/e/rpr2011.pdf.

[66] Katuwal H, Bohara AK. Biogas: A promising renewable technology and its impact on rural households in Nepal. Renew. and Sustainable Energy Reviews 2009;13: 2668-74. doi:10.1016/j.rser.2009.05.002.

[67] Park SC, Vitale J, Turner JC, Hattey JA, Stoecker A. Economic Profitability of Sustained Application of Swine Lagoon Effluent and Beef Feedlot Manure Relative to Anhydrous Ammonia in the Oklahoma Panhandle. Agronomy J. 2010;102(2): 420. doi:10.2134/agronj2009.0166.

[68] Omer AM, Fadalla Y. Biogas energy technology in Sudan. Renew. Energy 2003;28: 499507. doi:10.1016/S0960-1481(02)00053-8.

[69] Palmer, C., Engel, S. Avoided Deforestation-Prospects for Mitigating Climate Change. New York: Taylor \& Francis Group; 2009.

[70] Bellassen V, Luyssaert S. Carbon sequestration: Managing forests in uncertain times. Nature 2014;506: 153-155. doi:10.1038/506153. 
[71] Kaimowitz D, Angelsen K. Economic Models of Tropical Deforestation- A Review. Indonesia: Center for International Forestry Research; 1998.

[72] Energy Sector Management Assistance Program (ESMAP). Haiti: Strategy to Alleviate the Pressure of Fuel Demand on National Woodfuel Resources. The International Bank for Reconstruction and Development/The World Bank; 2007.

[73] Wampler PJ, Sisson AJ. Spring flow, bacterial contamination, and water resources in rural Haiti. Environmental Earth Sciences 2010;62(8): 1619-28. doi: 10.1007/s12665-0100645-9.

[74] Subedi M, Matthews RB, Pogson M, Abegaz A, Balana BB, Oyesiku-Blakemore J, Smith J. Can biogas digesters help to reduce deforestation in Africa? Biomass and Bioenergy 2014;70: 87-98. doi:10.1016/j.biombioe.2014.02.029.

[75] Schlag N, Zuzarte F. Market Barriers to Clean Cooking Fuels in Sub-Saharan Africa: A Review of Literature. Stockholm, Sweden: Stockholm Environment Institute; 2008.

[76] Miller TP, Peterson JR, Lenhart CF, Nomura Y. The Agricultural BMP Handbook for Minnesota. Minnesota Department of Agriculture; 2012.

[77] Dufour A, Bartram J, Bos R, Gannon V. Animal Waste, Water Quality and Human Health. London, UK: IWA Publishing; 2012.

[78] Masse D, Gilbert Y, Topp E. Pathogen removal in farm-scale psychrophilic anaerobic digesters processing swine manure. Bioresource Technology 2011;102: 641-6.

[79] Côte C, Massé DI, Quessy S. Reduction of indicator and pathogenic microorganisms by psychrophilic anaerobic digestion in swine slurries. Bioresource Technology 2006;97: 686-91. doi:10.1016/j.biortech.2005.03.024. 
[80] Cecelski E. The Role of Women in Sustainable Energy Development. Golden, Colorado: National Renewable Energy Laboratory; 2000. Retrieved November 18, 2014 from http://www.nrel.gov/docs/fy00osti/26889.pdf.

[81] Cecelski E. Energy and Rural Women's Work: Crisis, Response and Policy Alternatives. International Labor Rev. 1987;126(1): 41-64.

[82] Gautam R, Baral S, Herat S. Biogas as a Sustainable Energy Source in Nepal: Present Status and Future Challenges. Renew. and Sustainable Energy Reviews 2009;13: 248-52. doi: 10.1016/j.rser.2007.07.006.

[83] Nigel, B, Perez-Padilla, R, Albalak, R. Indoor air pollution in developing countries: a major environmental and public health challenge. Special theme: Environment and Health; Bulletin of the World Health Organization, 2000; 78(9): 1078-92. Retrieved July 22, 2015 from http://www.who.int/bulletin/archives/78(9)1078.pdf

[84] Ritz B, Yu F. The effect of ambient carbon monoxide on low birth weight among children born in southern California between 1989 and 1993. Environmental Health Perspectives 1999;107: 17-25.

[85] Ezzati M, Kammen D. Quantifying the effects of exposure to indoor air pollution from biomass combustion on acute respiratory infections in developing countries. Environmental Health Perspectives 2001;109: 481-8.

[86] Bonte J. Patterns of Mortality and Morbidity. In: Vogel LC, Muller AS, Odingo RS, Onyango A, De Geus A, editors. Health and disease in Kenya. Nairobi, Kenya: East African Literature Bureau; 1974. p. 75-90. http://www.popline.org/node/516285\#sthash.FkhZF96x.dpuf. 
[87] Ezzati M, Kammen DM. Household energy, indoor air pollution and health in developing countries: Knowledge base for effective intervention. Annual Rev. of Energy and the Environment 2002;27: 233-70.

[88] Ribeiro H, Cardoso MRA. Air pollution and children's health in Sao Paulo (1986-1998). Soc. Science and Medicine 2003;57: 2013-22.

[89] World Health Organization (WHO). Indoor air pollution: National burden of disease estimates; 2007. Retrieved November 18, 2014 from http://www.who.int/indoorair/publications/indoor_air_national_burden_estimate_revised. pdf?ua=1

[90] Laichena JK, Wafula JC. Biogas technology for rural households in Kenya. Organization of the Petroleum Exporting Ctries. Rev. 1997;21(3): 223-4. doi: 10.1111/j.14680076.1997.tb00009.x.

[91] United Nations Environmental Programme (UNEP). Waste and Climate Change: Global Trends and Strategy Framework. International Environmental Technology Centre; 2010.

[92] Asian Development Bank (ADB). PRC: Efficient Utilization of Agricultural Wastes Project; 2010. Retrieved November 1, 2014 from http://www.thegef.org/gef/sites/thegef.org/files/gef_prj_docs/GEFProjectDocuments/Ma ndE/EO_TEs_FY13/ADB_TEs_APR2013/1105_ADB_TE_and_TER/1105_ADB_TE_3 3443-01-PRC-PCR.pdf.

[93] National Biodigester Programme (NBP). Cambodia; 2014. Retrieved on November 1, 2014 from http://nbp.org.kh/Result.aspx. 
[94] Shealy S. Potentiality of biogas and the role of substrates in biogas formation potential. University of Colorado, Boulder; 2007. Retrieved July 9, 2015 from http://digitalcollections.sit.edu/cgi/viewcontent.cgi?article=1218\&context=isp_collection.

[95] Booth S, Funk K, Haase S. Haiti Waste-to-Energy Opportunity Analysis. Golden, Colorado: National Renewable Energy Laboratory; 2010.

[96] Hamad MA, Dayem AMA, Halwagi MM. Evaluation of the performance of two rural biogas units of Indian and Chinese design. Energy in Agriculture 1982;1: 235-50.

[97] Cortsen L, Lassen M, Nielsen HK. Small scale biogas digesters in Turiani, Nronga and Amani Tanzania. In: Furze, J, editor. Tubular Plastic Bio-Digesters in Tanzania, Vietnam, Zimbabwe and China, Ebeltoft, Denmark: University of Aarhus; 1995, p. 3682. Retrieved July 28, 2014 from http://www.journeytoforever.org/biofuel_library/biogasPlastictube.pdf.

[98] Thy S, Preston TR, Ly J. Effect of retention time on gas production and fertilizer value of biodigester effluent. Livest. Res. for Rural Development 2003;15(7). Retrieved July 21, 2015 from http://www.lrrd.org/lrrd15/7/sant157.htm.

[99] Müller ZO. Feed from Animal Wastes: State of knowledge. Rome, Italy: Food and Agriculture Organization of the United Nations; 1980.

[100] Fulhage CD, Siever D, Fischer JR. Generating Methane Gas from Manure. Stanford University, Department of Agricultural Engineering; 1993. Retrieved July 21, 2015 from http://large.stanford.edu/publications/coal/references/docs/fulhage.pdf.

[101] Specific Heats. Retrieved October 28, 2014, from http://www.engineeringtoolbox.com/. 
[102] Tucker MR. Essential plant nutrients: Their presence in North Carolina soils and role in plant nutrition; 1999. Retrieved October 10, 2013 from http://www.ncagr.gov/agronomi/pdffiles/essnutr.pdf.

[103] Chislock MF, Doster E, Zitomer RA, Wilson AE. Eutrophication: Causes, Consequences, and Controls in Aquatic Ecosystems. Nature Education Knowl. 2013;4(4): 10.

[104] Au D, Pollino C, Wu R, Shin P, Lau S, Tang J. Chronic effects of suspended solids on gill structure, osmoregulation, growth, and triiodothyronine in juvenile green grouper Epinephelus coioides. Marine Ecology Prog. Ser. 2004;266: 255-64.

[105] EPA. Pacific Southwest Animal Waste: What's the problem? 2011. Retrieved November 30, 2014 from http://www.epa.gov/region9/animalwaste/problem.html.

[106] Africabiogas.org [Internet]. Nairobi: Africa Biogas Partnership Progamme; 2014. Retrieved July 5, 2015 from http://africabiogas.org/.

[107] Boers, W., Workneh, K., Esthete, G. National Biogas Programme Ethiopia Programme Implementation Document. Addis Ababa, Ethiopia: Ethiopia Rural Energy Development and Promotion Centre; 2008.

[108] Ngigi, A. Kenya National Domestic Biogas Programme. An initiative under the Africa Biogas Partnership Programme [Internet]. Nairobi, Kenya: Integral Advisory Limited c2009. Retrieved July 5, 2015 from http://www.ewbusa.org/files/2015/05/biogas_programme_implementation_kenya.pdf.

[109] Abbasi T, Tauseef SM, Abbasi SA. Biogas Energy. New York: Springer Science \& Business Media, LLC; 2012. 
[110] Bhattacharya, SC, Jana C. Renewable energy in India: Historical developments and prospects. Energy [special issue]. 2009 August; 34(8): 981-91. doi:10.1016/j.energy.2008.10.017

[111] MNRE.gov.in [Internet]. Government of India, Ministry of New and Renewable Energy. National Biogas and Manure Management Programme.; c2012. Retrieved July 5, 2015 from http://mnre.gov.in/schemes/decentralized-systems/schems-2/.

[112] Biogas.org.vn [Internet]. Hanai, Vietnam: Biogas Program for the Animal Husbandry Sector in Vietnam. c2007-2015. Retrieved July 5, 2015 from http://www.biogas.org.vn/english/Our-Activities/Financial-facilitation.aspx.

[113] Parker c. Biogas Digesters for Cambodians: A multi-partner national biodigester program in Cambodia.; c2011. Retrieved July 5, 2015 from http://www.unep.org.

[114] Phanthavongs S, Saikia U. Biogas digesters in small pig farming systems in Lao PDR: evidence of an impact. Livestock Research for Rural Development 2013; 25(12). Retrieved July 21, 2015 from http://www.lrrd.org/lrrd25/12/phan25216.htm.

[115] Garwood A. Network for Biodigesters in Latin America and the Caribbean: Case Studies and Future Recommendations. Inter-American Development Bank: Sustainable Energy \& Climate Change Unit Infrastructure and Environment Sector; 2010. Technical note No.: IDB-TN-207.

[116] Kinyua, M.N. Energy production and effluent quality in tubular digesters treating livestock waste in rural Costa Rica. (Doctorate dissertation). University of South Florida, Tampa, FL. 2015. 
[117] Pedraza G, Chará J, Conde N, Giraldo S, Giraldo L. Evaluation of polyethylene and PVC tubular biodigesters in the treatment of swine wastewater. Livestock Research for Rural Development 2002; 14 (1). Retrieved November 14, 2015 from http://www.lrrd.org/lrrd14/1/Pedr141.htm

[118] An B.X. Biogas technology in developing countries: Vietnam case study. Proceedings from the International Workshop Research and Development on Use of Biodigesters in SE Asia region 2002; Retrieved November 14, 2015 from http://www.mekarn.org/procbiod/an.htm

[119] Vietnam Biogas Association. International Workshop on Small- and Medium-Scale Biogas in Vietnam 2013. Retrieved November 14, 2015 from http://vietnambiogas.org.vn/

[120] Thy S, Preston T R, Borin K, Buntha P, Vanvuth T. The optimization of gas production in tubular plastic biodigesters by charging with different proportions of pig and cattle manure. Livestock Research for Rural Development 2005; 17 (12). Retrieved November 14, 2015 from http://www.lrrd.org/lrrd17/12/sant17132.htm

[121] Phiny C, Borin K, Preston T. R, Ty C. Effect of level of effluent from biodigesters loaded with pig manure on the growth of mulberry (Morus alba) trees. Livestock Research for Rural Development 2009; 21 (7). Retrieved November 14, 2015 from http://www.lrrd.org/lrrd21/7/phin21114.htm

[122] Nouanthavong T, Preston T R. Effect of biodigester effluent, duckweed and leaves from Taro (Colocacia esculenta) on growth of Tilapia (Oreochromis niloticus) in open ponds. Livestock Research for Rural Development 2012; 24 (2). Retrieved November 14, 2015 from http://www.lrrd.org/lrrd24/2/tick24025.htm 
[123] Tu D.T.M, Dong, N T K, Preston T R. Effect on composition of duckweed (Lemna minor) of different levels of biodigester effluent in the growth medium and of transferring nutrient-rich duckweed to nutrient-free water. Livestock Research for Rural Development 2012; 24 (4). Retrieved November 14, 2015 from http://www.lrrd.org/lrrd24/4/mytu24071.htm 


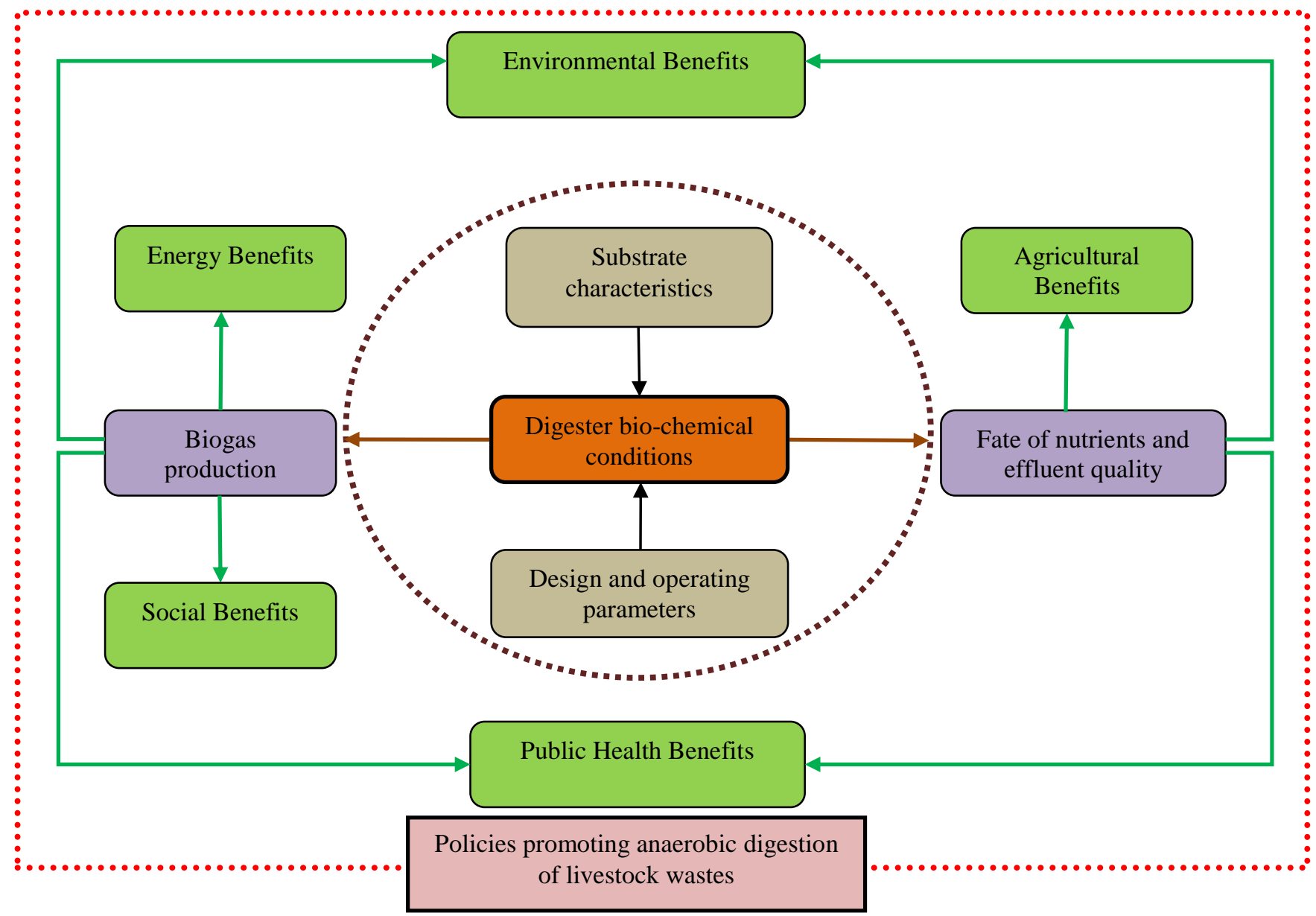

Fig 1: Schematic illustrating link between digester operation, benefits and policies. 


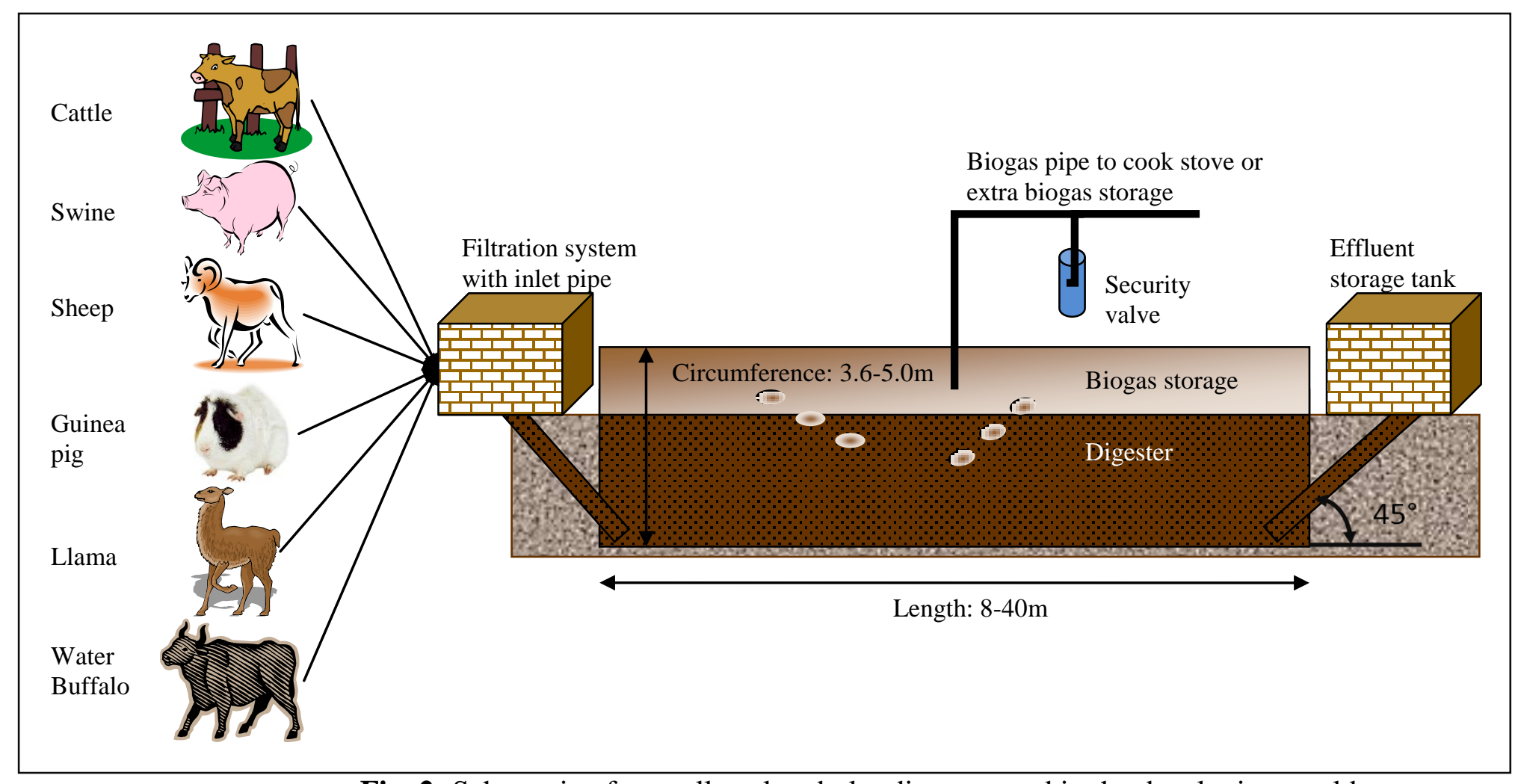

Fig. 2: Schematic of a small-scale tubular digester used in the developing world 

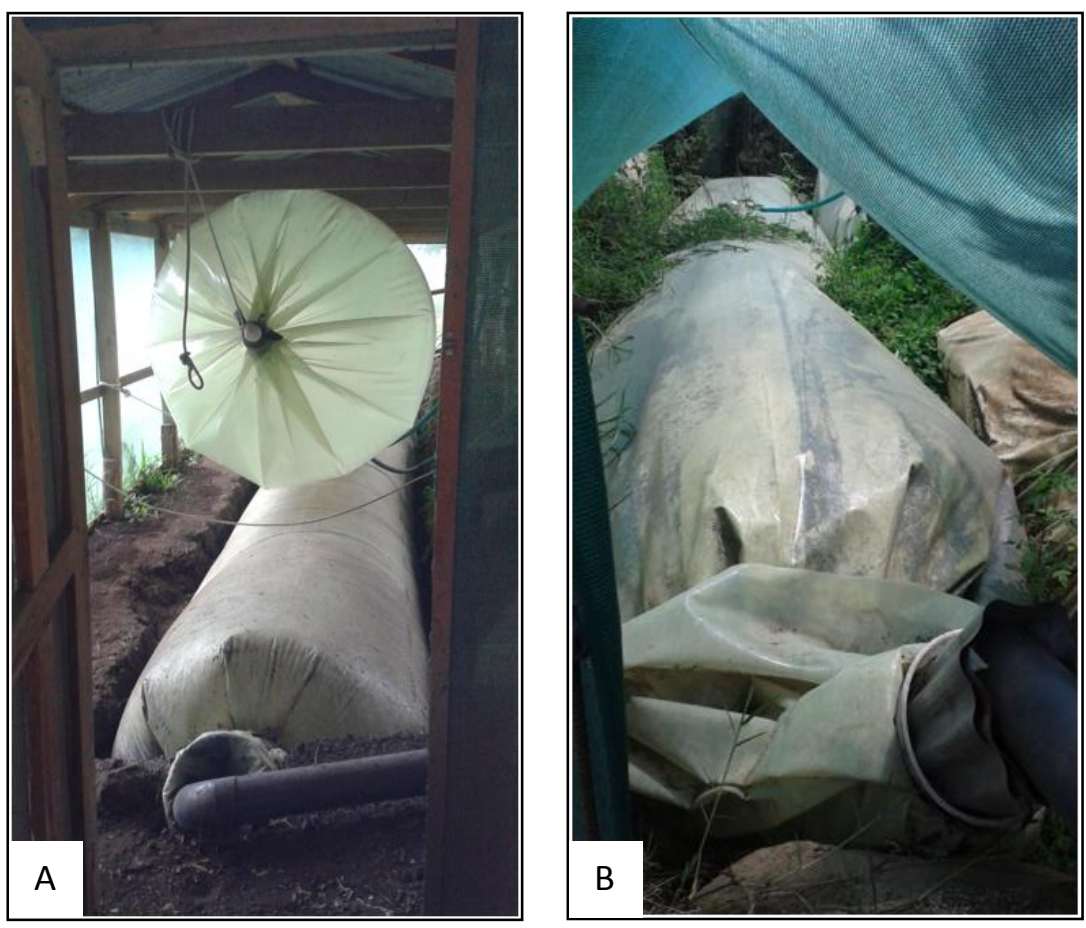

Fig. 3: Images of tubular digesters with and without a biogas storage bag treating swine waste in Costa Rica 


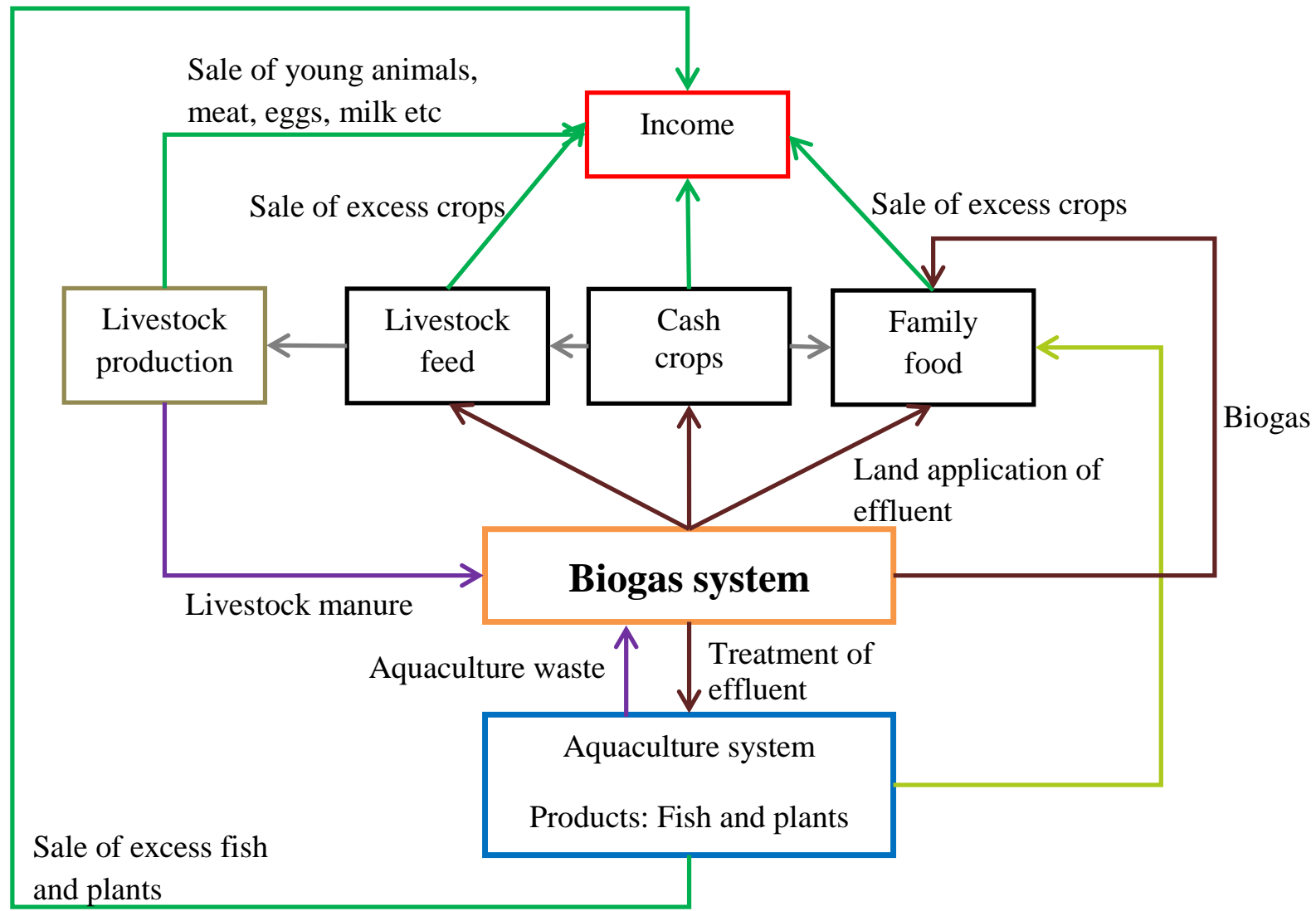

Fig 4: Biogas system contribution in an integrated farming framework (adapted from [94]) 
Table 1: Summary of substrate characteristics, operating parameters and performance of tubular digesters installed in different regions of the developing world to treat livestock waste.

\begin{tabular}{|c|c|c|c|c|c|c|c|c|c|c|}
\hline Region & Country & $\begin{array}{l}\text { Type of } \\
\text { Manure }\end{array}$ & $\begin{array}{c}\text { TAN } \\
\text { concentration } \\
g N H_{4}^{+}-N / L\end{array}$ & $\mathbf{p H}$ & $\begin{array}{c}\text { Organic } \\
\text { Loading } \\
\text { Rate } \\
\mathrm{kg} \mathrm{VS} / \mathrm{m}^{3}- \\
\quad d a y \\
\end{array}$ & $\begin{array}{c}\text { Retention } \\
\text { Time } \\
\text { Day }\end{array}$ & Temperature & $\begin{array}{c}\text { Biogas Yield } \\
m^{3} \text { biogas } / k g \\
V S_{\text {added }}\end{array}$ & $\begin{array}{c}\mathbf{C H}_{4} \\
\text { content } \\
\%\end{array}$ & Reference \\
\hline \multirow{3}{*}{ Africa } & Egypt & Water Buffalo & $\mathrm{n} / \mathrm{a}$ & $\mathrm{n} / \mathrm{a}$ & $1.1-2.1$ & 38,58 and 95 & $17-22$ & $0.04-0.16$ & $43-66$ & [96] \\
\hline & Tanzania & Cow & $\mathrm{n} / \mathrm{a}$ & $\mathrm{n} / \mathrm{a}$ & $0.33-3.9$ & $19-23$ & $\mathrm{n} / \mathrm{a}$ & $0.07-0.32$ & $62-76$ & [97] \\
\hline & Vietnam & Swine & $\mathrm{n} / \mathrm{a}$ & $6.5-6.6$ & $0.66-2.7$ & 30 & $25-27$ & $0.30-0.36$ & $54-56$ & [48] \\
\hline \multirow{4}{*}{ Asia } & Cambodia & Swine & $0.34-0.88$ & $6.8-7.1$ & 1.8 & $10-30$ & $26-31$ & $0.29-0.56$ & $\mathrm{n} / \mathrm{a}$ & [98] \\
\hline & Cambodia & Swine and cow & $0.22-0.60$ & $\mathrm{n} / \mathrm{a}$ & 3.27 & 20 & $\mathrm{n} / \mathrm{a}$ & $0.037-0.082$ & $\mathrm{n} / \mathrm{a}$ & [120] \\
\hline & Indonesia & Cow & $\mathrm{n} / \mathrm{a}$ & $7.3-7.7$ & 2.00 & 21 & 27 & $0.14-0.15^{\mathrm{d}}$ & 59 & {$[46]$} \\
\hline & Bolivia & $\begin{array}{c}\text { Cow, llama and } \\
\text { sheep }\end{array}$ & $\mathrm{n} / \mathrm{a}$ & $74-7.8$ & $0.50-8.00$ & 10,20 and 30 & 18 and 25 & $0.013-0.19$ & $21-61$ & [43] \\
\hline \multirow{4}{*}{$\begin{array}{c}\text { Central and } \\
\text { South } \\
\text { America }\end{array}$} & Colombia & Swine & $0.086-0.39$ & 6.8 & $0.69^{\mathrm{b}}$ & 15 & 23 & $0.19-0.27$ & $\mathrm{n} / \mathrm{a}$ & [117] \\
\hline & $\begin{array}{l}\text { Costa } \\
\text { Rica }\end{array}$ & $\begin{array}{l}\text { Swine and } \\
\text { grease }\end{array}$ & $1.1-1.4$ & $6.9-7.2$ & $0.50-1.4^{\mathrm{c}}$ & 40 & $22-26$ & $\mathrm{n} / \mathrm{a}$ & $63-70$ & [9] \\
\hline & Peru & Cow & $0.14-1.11^{\mathrm{a}}$ & $7.7-8.3$ & $0.67-1.00$ & $60-90$ & $20-25$ & 0.35 & $63-67$ & [44] \\
\hline & Peru & Guinea Pig & $0.20-0.21$ & $7.2-8.8$ & 0.60 & 75 & $23-30$ & $0.058-0.061$ & $61-73$ & [13] \\
\hline
\end{tabular}

$\mathrm{a}=\mathrm{mg} / \mathrm{g} ; \mathrm{b}=$ assuming $6.5 \% \mathrm{VS} ; \mathrm{c}=\mathrm{kg} \mathrm{COD} / \mathrm{m}^{3}$-day; $\mathrm{d}=\mathrm{m}^{3} \mathrm{CH}_{4} / \mathrm{kg} \mathrm{VS}_{\text {added }} ; \mathrm{n} / \mathrm{a}$ stands for not available 
Table 2: Nutrient content and recalcitrant compounds in livestock manure [19, 30 and 99]

\begin{tabular}{llccc}
\hline Parameter & Unit & Swine & Cow & Poultry \\
\hline Lignin & $\%$ VS & $2.2-16$ & $7.9-10$ & $3.4-5.2$ \\
Cellulose & $\%$ VS & $15-20$ & $17-25$ & $11-15$ \\
Hemicellulose & $\%$ VS & 20 & 22 & $11-17$ \\
Nitrogen & kg/day-animal & $0.037-0.95$ & $0.22-0.33$ & $0.002-0.01$ \\
Phosphorus & kg/day-animal & $0.024-0.25$ & $0.08-0.14$ & $0.001-0.37$ \\
Potassium & kg/day-animal & $0.028-0.26$ & $0.12-0.19$ & $0.001-0.46$ \\
\hline
\end{tabular}


Table 3: Calculated average potential biogas and heat energy produced per animal calculated depending on manure type

\begin{tabular}{|c|c|c|c|c|c|c|c|}
\hline \multirow[t]{2}{*}{ Type of manure } & \multirow[t]{2}{*}{ Unit } & \multicolumn{2}{|c|}{ Swine } & \multicolumn{2}{|c|}{ Cow } & \multirow[t]{2}{*}{ Poultry } & \multirow[t]{2}{*}{ Horse } \\
\hline & & Sow & Boar & Dairy & Beef & & \\
\hline Weight of excrete ${ }^{\text {a }}$ & kg/animal-day & 8.10 & 3.80 & 59.0 & 39.0 & 0.086 & 25.4 \\
\hline VS in excrete ${ }^{a}$ & kg/animal-day & 0.74 & 0.34 & 5.18 & 4.05 & 0.02 & 3.02 \\
\hline VS reduction at $20^{\circ} \mathrm{C}^{\mathrm{b}}$ & $\%$ & 49 & 49 & 31 & 41 & 56 & 31 \\
\hline Potential biogas yield $^{\mathrm{c}}$ & $\mathrm{m}^{3}$ biogas $/ \mathrm{kg} \mathrm{VS}$ & 0.34 & 0.35 & 0.25 & 0.092 & 0.43 & 0.28 \\
\hline $\begin{array}{l}\text { Potential biogas volume } \\
\text { produced }\end{array}$ & $\mathrm{m}^{3} \mathrm{CH}_{4} /$ animal-day & 0.15 & 0.06 & 0.52 & 0.16 & 0.004 & 0.26 \\
\hline $\begin{array}{l}\text { Potential methane volume } \\
\text { produced }\end{array}$ & $\mathrm{m}^{3}$ biogas/animal-day & 0.09 & 0.03 & 0.31 & 0.10 & 0.002 & 0.15 \\
\hline Heat energy production rate & MJ/animal-day & 1.6 & 0.62 & 5.5 & 1.7 & 0.042 & 2.7 \\
\hline
\end{tabular}

${ }^{\mathrm{a}}[19],{ }^{\mathrm{b}}[100],{ }^{\mathrm{c}}$ [47] 
Table 4: Calculated total heat energy requirements to boil $0.5 \mathrm{~kg}$ of different foods in different vessel material

\begin{tabular}{|c|c|c|c|c|c|c|}
\hline Vessel material & & Aluminum & Copper & Stainless steel & Clay pot & Cast iron \\
\hline Vessel material specific heat capacity $^{a}$ & $\mathrm{~kJ} / \mathrm{kg}-{ }^{\circ} \mathrm{C}$ & 0.90 & 0.85 & 0.50 & 0.94 & 0.46 \\
\hline Heat energy required to increase vessel temperature per degree & $\mathrm{kJ} /{ }^{\circ} \mathrm{C}$ & 0.45 & 0.43 & 0.25 & 0.47 & 0.23 \\
\hline Type of food & & Water & Beans & Rice & Potatoes & Eggs \\
\hline Heat energy required to increase water temperature per degree & $\mathrm{kJ} /{ }^{\circ} \mathrm{C}$ & 2.09 & 2.09 & 2.09 & 2.09 & 2.09 \\
\hline Heat energy required to increase food temperature per degree & $\mathrm{kJ} /{ }^{\circ} \mathrm{C}$ & & 0.59 & 2.09 & 1.72 & 1.59 \\
\hline
\end{tabular}

Heat energy required to increase item temperature per degree $=$ mass of item x specific heat capacity ; ${ }^{\mathrm{a}}[101]$ 
Table 5: Roles of primary nutrients during plant growth [102]

\begin{tabular}{lll}
\hline Nutrient & & \multicolumn{1}{c}{ Roles } \\
\hline Nitrogen & - Involved in photosynthesis. \\
& - Promotes plant growth as a component of cell division. \\
& - Increases quality and size of plants. \\
Phosphorus & - Assists in plant's protein synthesis through amino acids. \\
& - Involved in protein synthesis \\
& - Assists in seed development. \\
& - Makes plants less vulnerable to cold temperatures. \\
\hline
\end{tabular}


Table 6: Summary of pollutants found in raw livestock waste and their environmental impacts

\begin{tabular}{|c|c|c|}
\hline Pollutant & $\begin{array}{l}\text { Environmental Impacts } \\
\end{array}$ & References \\
\hline Biodegradable organic matter & $\begin{array}{l}\text { Degradation of biodegradable organic matter decreases } \\
\text { DO levels in water bodies which affect aquatic life. }\end{array}$ & [103] \\
\hline $\begin{array}{l}\text { Nutrients } \\
\quad \text { Nitrogen } \\
\text { Phosphorus }\end{array}$ & $\begin{array}{l}\text { High concentrations of nutrients promote excessive } \\
\text { growth of plants and algae. Decomposition of dead algae } \\
\text { decreases DO levels. This process is called eutrophication. }\end{array}$ & {$[103]$} \\
\hline Suspended solids & $\begin{array}{l}\text { Increase water turbidity, decreasing light penetration } \\
\text { which affects aquatic plants' photosynthesis process. } \\
\text { Suspended solids also accumulate in fish gills affecting } \\
\text { their growth rates and health. }\end{array}$ & {$[104]$} \\
\hline $\begin{array}{l}\text { Pathogens } \\
\text { Cryptosporidium, Giardia, } \\
\text { Campylobacter, Salmonella } \\
\text { and E. coli } O 157\end{array}$ & $\begin{array}{l}\text { Human exposure to pathogens in water bodies that are } \\
\text { used for drinking water, recreation and fishing. }\end{array}$ & [77] \\
\hline $\begin{array}{l}\text { Air pollutants } \\
\text { VOC, GHGs, odorous gases } \\
\text { and particulate matter }\end{array}$ & $\begin{array}{l}\text { Livestock waste decomposition forms air pollutants that } \\
\text { cause respiratory illness such as asthma, smog formation, } \\
\text { psychological stress from continued exposure and climate } \\
\text { change. }\end{array}$ & {$[105]$} \\
\hline Trace metals & $\begin{array}{l}\text { Copper, zinc and boron can negatively affect the } \\
\text { environment from accumulation in water bodies. }\end{array}$ & {$[6]$} \\
\hline Chemicals of concern & $\begin{array}{l}\text { Antibiotics and pharmaceuticals in water bodies affect } \\
\text { aquatic life }\end{array}$ & [6] \\
\hline
\end{tabular}


Table 7: Implementation of Biogas Systems and Market Trends in Africa

\begin{tabular}{|c|c|c|c|c|c|}
\hline Country & Agency Promoting Digesters & $\begin{array}{l}\text { Type of } \\
\text { Digester }\end{array}$ & Financial/Business Model & Market Trend & Reference \\
\hline $\begin{array}{l}\text { Burkina } \\
\text { Faso }\end{array}$ & & Fixed dome & $\begin{array}{l}\text { Government subsidy covered } 30 \% \text { of initial } \\
\text { investment cost }\end{array}$ & $\begin{array}{l}5,459 \text { biogas } \\
\text { systems } \\
\text { installed } \\
\text { between 2009- } \\
2014\end{array}$ & {$[106]$} \\
\hline Ethiopia & & Fixed dome & $\begin{array}{l}\text { Farmers contributed about } 11 \% \text { of the total } \\
\text { investment cost, received a } 32 \% \text { subsidy and a } \\
\text { microfinance loan for the remainder of the } \\
\text { investment cost. }\end{array}$ & $\begin{array}{l}9,825 \text { biogas } \\
\text { systems } \\
\text { installed } \\
\text { between } 2009- \\
2014\end{array}$ & $\begin{array}{l}{[106 \text { and }} \\
107]\end{array}$ \\
\hline Kenya & $\begin{array}{l}\text { The Africa Biogas Partnership Programme, a } \\
\text { collaboration between the Directorate General } \\
\text { for International Cooperation (DGIS) of the } \\
\text { Dutch Ministry of Foreign Affairs and } \\
\text { Humanist Institute for Cooperation with } \\
\text { Developing Countries (Hivos). }\end{array}$ & $\begin{array}{l}\text { Floating } \\
\text { drum, fixed } \\
\text { dome and } \\
\text { tubular }\end{array}$ & $\begin{array}{l}\text { A } 300 \text { USD ( } 25,000 \text { KSHS) subsidy was } \\
\text { provided regardless of system size and if needed, } \\
\text { a } 2 \text { year loan with a } 1 \% \text { monthly interest rate } \\
\text { from rural micro-finance institutions and saving } \\
\text { cooperatives }\end{array}$ & $\begin{array}{l}\text { Between } 2009 \\
\text { and } 2013 \text {, } \\
11,579 \text { biogas } \\
\text { systems were } \\
\text { installed }\end{array}$ & $\begin{array}{l}{[106 \text { and }} \\
108]\end{array}$ \\
\hline Tanzania & & $\begin{array}{l}\text { Fixed dome, } \\
\text { tubular and } \\
\text { solid state } \\
\text { digesters }\end{array}$ & $\begin{array}{l}\text { About } 38 \% \text { of the investment cost was financed } \\
\text { through a } 3 \text { year savings and credit cooperative } \\
\text { loan, } 62 \% \text { of the cost was financed through a } \\
\text { subsidy offered by Friends in Development Trust } \\
\text { Fund }\end{array}$ & $\begin{array}{l}10,000 \text { biogas } \\
\text { systems } \\
\text { installed } \\
\text { between 2009- } \\
2014\end{array}$ & {$[106]$} \\
\hline Uganda & & Fixed dome & $\begin{array}{l}\text { A } 200 \text { USD ( } 674,000 \text { UGX) subsidy was } \\
\text { provided through the program which covered } \\
\text { about a third of the investment cost. The farmers } \\
\text { were also provided } 3 \text { year loans through micro- } \\
\text { finance institutions with low interest rates }\end{array}$ & $\begin{array}{l}\text { Between } 2009 \\
\text { and } 2013,5,000 \\
\text { biogas systems } \\
\text { were installed }\end{array}$ & {$[106]$} \\
\hline
\end{tabular}


Table 8: Implementation of Biogas Systems and Market Trends in Asia

\begin{tabular}{|c|c|c|c|c|c|}
\hline Country & Agency Promoting Digesters & $\begin{array}{l}\text { Type of } \\
\text { Digester }\end{array}$ & Financial/Business Model & Market Trend & Reference \\
\hline Bangladesh & $\begin{array}{l}\text { Bangladesh Council of Scientific and } \\
\text { Industrial Research (BCSIR) and the } \\
\text { Local Government Engineering } \\
\text { Department (LGED) }\end{array}$ & Fixed dome & Not available & $\begin{array}{l}24,000 \text { biogas } \\
\text { systems installed as } \\
\text { of } 2012\end{array}$ & [109] \\
\hline Cambodia & $\begin{array}{l}\text { Cambodia Ministry of Agriculture, } \\
\text { National Biogas Programme }\end{array}$ & Fixed dome & $\begin{array}{l}\text { Two year loans with a } 1.2 \% \text { interest rate per } \\
\text { month }\end{array}$ & $\begin{array}{l}19,200 \text { biogas } \\
\text { systems installed } \\
\text { between } 2007-2013\end{array}$ & [93] \\
\hline China & $\begin{array}{l}\text { Governments of People's Republic of } \\
\text { China (PRC), Asian Development Bank } \\
\text { (ADB) and Global Environment Facility }\end{array}$ & Fixed dome & $\begin{array}{l}\text { Farmers received } 10 \text { year loans from village } \\
\text { economic cooperatives with a } 7.2 \% \text { interest } \\
\text { rate }\end{array}$ & $\begin{array}{l}19,000 \text { biogas } \\
\text { systems installed } \\
\text { between } 2006-2008\end{array}$ & [92] \\
\hline India & $\begin{array}{l}\text { Government of India Ministry of New } \\
\text { and Renewable Energy }\end{array}$ & $\begin{array}{l}\text { Floating drum, } \\
\text { fixed dome } \\
\text { and tubular }\end{array}$ & $\begin{array}{l}\text { Government subsidies provided were } \\
\text { dependent on region and the size of digesters. } \\
\text { Subsidies ranged from } 23 \text { to } 268 \text { USD } \\
(1,500-17,000 \text { INR })\end{array}$ & $\begin{array}{l}\text { As of } 2001,0.4 \% \text { of } \\
\text { total households } \\
\text { used biogas systems. }\end{array}$ & $\begin{array}{l}{[110 \text { and }} \\
111]\end{array}$ \\
\hline Laos & $\begin{array}{l}\text { Laos Ministry of Agriculture and } \\
\text { Forestry, Dutch Directorate General of } \\
\text { Development Cooperation, and US-based } \\
\text { Blue Moon Fund }\end{array}$ & Fixed dome & Not available & $\begin{array}{l}2,405 \text { biogas } \\
\text { systems installed } \\
\text { between } 2007-2011\end{array}$ & {$[106]$} \\
\hline Nepal & $\begin{array}{l}\text { Nepal Ministry of Science and } \\
\text { Technology, Alternative Energy } \\
\text { Promotion Center }\end{array}$ & Fixed dome & $\begin{array}{l}\text { A } 25 \% \text { government subsidy was provided for } \\
\text { the initial investment cost and an additional } \\
50 \% \text { subsidy on loan interest payment }\end{array}$ & $\begin{array}{l}189,122 \text { biogas } \\
\text { systems installed } \\
\text { between } 1992-2009\end{array}$ & {$[66]$} \\
\hline \multirow[t]{2}{*}{ Vietnam } & $\begin{array}{l}\text { Vietnam Ministry of Agricultural and } \\
\text { Rural Development and the Netherlands } \\
\text { Development Organization }\end{array}$ & Fixed dome & $\begin{array}{l}\text { A } 10 \% \text { government subsidy was provided to } \\
\text { support a capital cost of } 550 \text { USD ( } 11 \\
\text { million VND) }\end{array}$ & $\begin{array}{l}200,000 \text { biogas } \\
\text { systems installed } \\
\text { between } 2003-2013\end{array}$ & $\begin{array}{l}{[112,118} \\
\text { and } 119]\end{array}$ \\
\hline & & Tubular & $\begin{array}{l}\text { As of } 2000 \text { farmers paid } 60 \text { USD for the } \\
\text { digesters }\end{array}$ & & \\
\hline
\end{tabular}


Table 9: Implementation of Biogas Systems and Market Trends in Latin America

\begin{tabular}{|c|c|c|c|c|c|}
\hline Country & Agency Promoting Digesters & $\begin{array}{l}\text { Type of } \\
\text { Digester }\end{array}$ & Financial/Business Model & Market Trend & Reference \\
\hline Bolivia & $\begin{array}{l}\text { Partnership between Energizing Development } \\
\text { Partnership, Centro Internacional de Métodos } \\
\text { Numéricos para Ingeniería (CIMNE) of Spain and } \\
\text { the Universidad Mayor de San Antonio }\end{array}$ & Tubular & $\begin{array}{l}\text { Farmers contribute approximately } 80 \% \text { of the } \\
\text { capital cost } 110-175 \text { USD }(758-1,206 \text { BOB })\end{array}$ & $\begin{array}{l}\text { As of } 2010,275 \\
\text { biogas systems } \\
\text { installed }\end{array}$ & [115] \\
\hline $\begin{array}{l}\text { Costa } \\
\text { Rica }\end{array}$ & $\begin{array}{l}\text { Partnership between Earth University and } \\
\text { international and local educational institutions }\end{array}$ & Tubular & $\begin{array}{l}\text { Farmers contribute labor to install system } \\
\text { and some materials. Biogas systems cost } 200 \\
\text { USD }(107,280 \text { CRC) }\end{array}$ & $\begin{array}{l}\text { As of } 2015, \\
2010 \text { biogas } \\
\text { systems } \\
\text { installed }\end{array}$ & $\begin{array}{l}{[115 \text { and }} \\
116]\end{array}$ \\
\hline Ecuador & CARE and Northern Technical University (UTN) & Tubular & $\begin{array}{l}\text { Farmers contribute labor to install system } \\
\text { and some materials. Biogas systems cost } \\
500-750 \text { USD }\end{array}$ & $\begin{array}{l}\text { As of } 2010,20 \\
\text { biogas systems } \\
\text { installed }\end{array}$ & {$[115]$} \\
\hline Mexico & International Renewable Resources Institute-Mexico & Tubular & $\begin{array}{l}\text { Farmers contribute } 50 \% \text { of the capital cost } \\
378 \text { USD }(5,000 \mathrm{MXN})\end{array}$ & $\begin{array}{l}\text { Number of } \\
\text { biogas systems } \\
\text { was not reported }\end{array}$ & {$[115]$} \\
\hline Nicaragua & Asociacion Fenix & Tubular & $\begin{array}{l}\text { Farmers contribute } 100 \% \text { of capital and labor } \\
\text { costs. Biogas systems cost } 60-700 \text { USD } \\
(1,637-19,095 \mathrm{NIO})\end{array}$ & $\begin{array}{l}\text { As of } 2010,10 \\
\text { biogas systems } \\
\text { installed }\end{array}$ & {$[115]$} \\
\hline Peru & Soluciones Prácticas & Tubular & $\begin{array}{l}\text { Farmers contribute labor to install system, } \\
\text { some materials and } 10 \% \text { of the system cost. } \\
\text { Biogas systems cost } 640 \text { USD }(1,800 \text { PEN })\end{array}$ & $\begin{array}{l}\text { As of } 2010,25 \\
\text { biogas systems } \\
\text { installed }\end{array}$ & {$[115]$} \\
\hline
\end{tabular}

